\title{
16 Thermal Processing of Fruits and Fruit Juices
}

\author{
Catherine M.G.C. Renard and Jean $\overline{\overline{\bar{v}}}$ ncois Maingonnat
}

\section{CONTENTS}

16.1 Introduction

16.2 Microbial Considerations in Fruits Thermal Processing.......................................................... 414

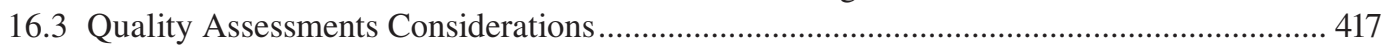

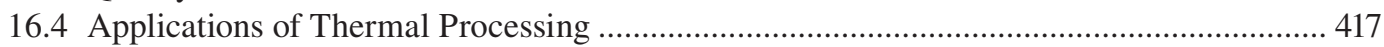

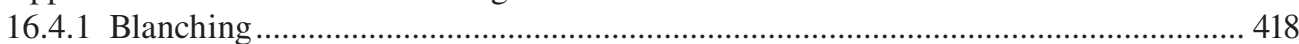

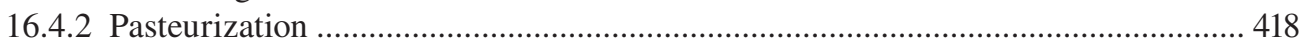

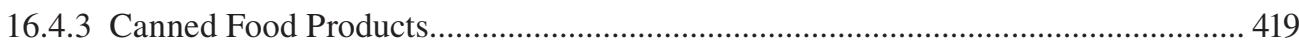

16.4.4 Continuous Sterilization and Aseptic Processing..................................................... 420

16.5 Quality Attribute Modifications during Thermal Processing of Fruits.................................420

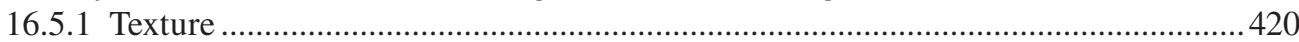

16.5.1.1 Thermal Softening of Fruits ........................................................................ 422

16.5.1.2 Rheological Behavior of Purees and Compotes ...................................... 423

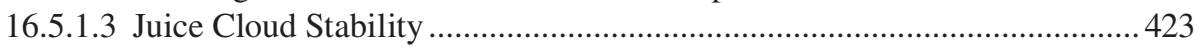

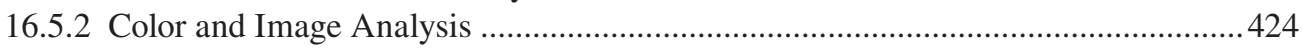

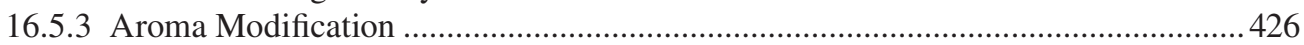

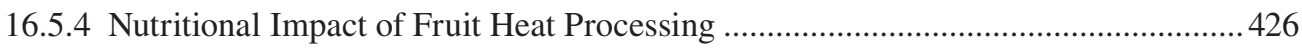

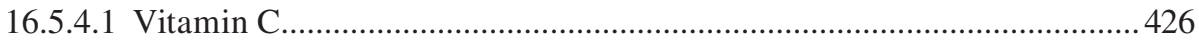

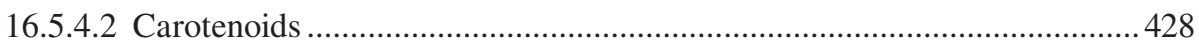

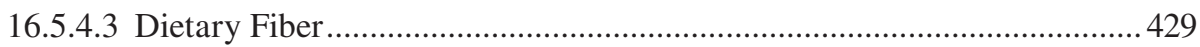

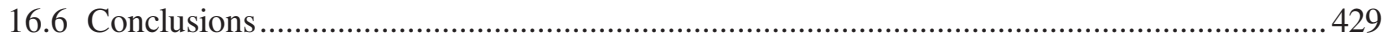

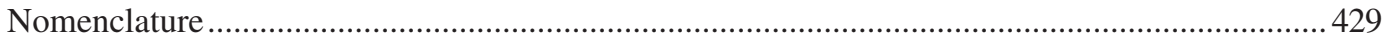

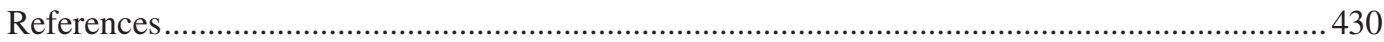

\subsection{INTRODUCTION}

The proportion of fruits that are eaten after processing has greatly increased in the last decade, with in particular a remarkable expansion and diversification of fruit juices. Canning comes a far second, while fresh-cut (outside the scope of this chapter) and puréed products have also received renewed interest. There is a steady industrial demand for cooked chilled or frozen intermediate products, most of which are further processed, for example, in jams or frozen desserts. Concentrated juices are a commodity on the world market. As most fruits are of relatively low $\mathrm{pH}$ (lower than 4.5), the microbial safety of fruit products only requires mild heat treatments (pasteurization) even for long-term stability at room temperature. The limiting factors in thermal treatments of fruits are therefore more linked to physicochemical properties. The first limiting factor often is inactivation of endogenous enzymes, some of which can be relatively heat resistant. The typical example is pectin methylesterase, which is linked to cloud instability in fruit juices. The thermal treatments applied 
to jams are also conditioned by the physical properties of the final products and the need to reach high sugar concentrations while ensuring pectin hom peous distribution throughout the product. In fruit juice concentrates or to a lesser extent puree $\overline{\bar{p}}$ ducts, cumulative thermal treatments will be dominated by the evaporation steps.

At the same time, new technologies are now coming to market, either as alternative heating systems such as ohmic, radio frequency heating, or using additional physical phenomena for microbial inactivation (high-pressure processing, pulsed electric field). Juices are still the main area of interest for these new technologies, with again a difficulty to ensure sufficient enzyme inactivation for physicochemical stability. Much less experience has been accumulated on these techniques, and in spite of numerous publications in the last few years [1-4], more experimental approaches are still required at all levels. Many recent publications compare these "nonthermal" technologies with more classical pasteurization, either conventional or high temperature-short time. Major interests and innovations can lie in exploiting the potential for synergisms between heat and these physical phenomena [5], a field still scarcely explored.

Quality aspects of fruits concern their sensory properties (aroma, taste, texture, and color) and nutritional qualities. Texture and color, being amenable to physicochemical methods of (relatively) high throughput and normalized values have been the most extensively studied. Softening is an expected result of heat treatment, which can be used, for example, prior to sieving for puréed products. Only moderate heat treatments are usually applied to fruits, some of them being very sensitive to extensive texture degradation and tissue disintegration; this sensitivity is species dependant and variety dependant $[6 \equiv$ ew publications have focused on the impact of heat treatments on volatiles in fruit juices, notable orange and apple [8-10].

From a nutritional point of view, most fruits contribute primarily to sugars intake, and their interest further resides in food volume and water intake. A few fruits can contain significant amounts of starch (unripe banana or apple) or fat (avocado or olives). In terms of micronutrients, fruits and fruit products are the main source of vitamin C. They contribute to potassium and calcium ions, fibers, and provitamin A. Most data available deal with losses in vitamin $\mathrm{C}$ in fruit juices as a function of treatment and storage. Vitamin $\mathrm{C}$ is also frequently used as a processing aid, for inhibition of enzymatic browning (notably for cloudy juices and purées); and the concentrations that are added can be much higher than those of the endogenous vitamin $\mathrm{C}$.

The objective of this chapter is to provide an overview of the recent results and advances on the impact of processing on safety and quality of heat-processed fruits, and of the models that have been developed to deal with microbial safety insurance as well as nutritional or physicochemical characteristics.

\subsection{MICROBIAL CONSIDERATIONS IN FRUITS THERMAL PROCESSING}

The surfaces of fruits contain diverse microorganisms that are normal microflora plus the microorganisms inoculated during processing [11] and recontamination on the process lines. One of the most convenient ways to limit the microbial risk is to increase the food temperature up to a lethal value for the microorganisms. This procedure is pasteurization if the vegetative forms are destroyed and sterilization if both vegetative and spores are destroyed. Recently, minimally processed fruits and vegetables [12] or cooked and chilled [13] foods containing fruits are frequently proposed to the consumers, and the microbial safety of such products is studied.

The food products are divided into two categories based on $\mathrm{pH}$ : acid foods $(\mathrm{pH}<4.5)$ and nonacid foods ( $\mathrm{pH}>4.5$ ). The acid foods are less critical because Clostridium botulinum, a strictly anaerobic spore-forming (thus heat-resistant) and toxin-producing bacteria, cannot grow at $\mathrm{pH}<4.5$. Most of the fruits are acid foods, the $\mathrm{pH}$ varying from 1.8 for limes, 3.5 for apples, to 6.5 for melons.

The main targets of thermal treatment are reduction of microorganisms and enzyme inactivation. The effects of thermal treatment are evaluated by the microorganism destruction, the enzyme inactivation, the quality loss, etc. These food component modifications are generally modeled with the reactions kinetic concept [14]. 
The basis of microbial inactivation has been the assumption that the microbial mortality at constant temperature obeys the following irreversible first-order kinetics:

$$
\frac{\mathrm{d} N(t)}{\mathrm{d} t}=-k(\vartheta) N(t)
$$

where

$N(t)$ is the number of microorganism at the time $t$

$k(\vartheta)$ is the temperature $\vartheta$-dependent inactivation "rate constant"

The solution of this first-order kinetic reaction is exponential and generally translated in terms of the well-known " $D$ value," which is the time in minutes to reduce the microbial population by one-log cycle (base 10):

$$
\log _{10}\left(\frac{N(t)}{N_{0}}\right)=-D(\vartheta) t \quad \text { with } D(\vartheta)=\frac{\ln (10)}{k(\vartheta)}
$$

where $N_{0}$ is the initial number of microorganisms.

The temperature influence on the $D$ value is traditionally assumed to be a log-linear relation, so that a plot of the $D$ value versus temperature in semilogarithmic coordinates is a straight line. The popular $z$ value is defined as the temperature change required to change the $D$ value by a factor of 10 , as given in the following:

$$
\log _{10}\left(\frac{D(\vartheta)}{D_{r e f}}\right)=\frac{\vartheta_{r e f}-\vartheta}{z}
$$

For the pathogenic bacteria (C. botulinum, Bacillus cereus, Bacillus subtilis, and Clostridium perfringens), the $z$ values vary generally between $8^{\circ} \mathrm{C}$ and $11^{\circ} \mathrm{C}$.

The reference temperatures are chosen as a function of the process design: $121.1^{\circ} \mathrm{C}$ for sterilization, $70^{\circ} \mathrm{C}$ for pasteurization; for more thermosensitive microorganisms, this reference temperature can be lower.

A very common concept is the process thermal lethality $F$, which is the product of the $D$ value at the chosen temperature by the number of decimal reduction required. For example, the "12D" concept applied to $C$. botulinum at $121.1^{\circ} \mathrm{C}$ leads to a $12 \times 0.21=2.52 \mathrm{~min} F$ value. To achieve a predetermined $F$ value, the thermal history of the process should be taken into account:

$$
F=\int_{0}^{t} 10^{\left(\vartheta-\vartheta_{r e f}\right) / z t}
$$

The first-order kinetic microorganism destruction is inappropriate when the isothermal survival semilogarithmic curves are nonlinear. Such nonlinearity has been observed for different microorganisms and spores [15], and alternative models are proposed [16]. One of the simplest is derived from the cumulative Weibull distribution and is written as follows [17]:

$$
\log _{10}\left(\frac{N(t)}{N_{0}}\right)=-\left(\frac{t}{b(\vartheta)}\right)^{\beta}
$$

where $b(\vartheta)$ and $\beta$ are the temperature-dependent parameters of the model. When $\beta=1$, the model is the first-order kinetic (Equation 16.2), $\beta<1$ corresponds to concave upward survival curves, and $\beta>1$ corresponds to concave downward curves [18]. 


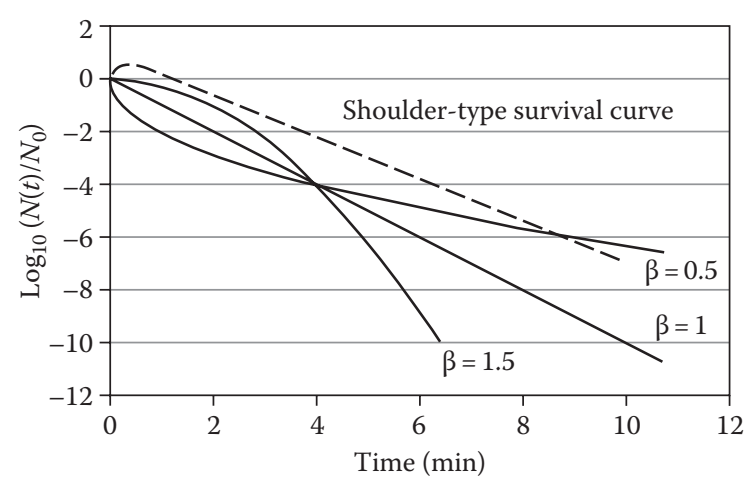

FIGURE 16.1 Simulated survival curves showing the effect of Weibull (Equation 16.5) parameter $\beta$ and a shoulder-type survival curve.

The survival curves can also exhibit some "shoulders" for short treatment times [19] and tailing effects at long treatment time or a sigmoid form [20]. The shapes of these different survival curves are schematically presented in Figure 16.1, and a software tool [21] is also available to fit the different types of survival curves.

Another type of microorganism destruction model is the so-called biphasic model [22] as defined in the following:

$$
\frac{N(t)}{N_{0}}=q \exp \left(-k_{1} t\right)+(1-q) \exp \left(-k_{2} t\right)
$$

where $q$ is a partition factor. Equation 16.6 has been applied for thermal inactivation of $C$. botulinum [23] or high-pressure effect on Escherichia coli in liquid whole egg [24].

The fittings of different survival curves and their influence on the heating processes have been recently reviewed [25]. Although the classical first-order kinetic model is frequently used, an optimization (quality assessments, energy saving, etc.) of the thermal processes [26] should take into account these new types of modeling.

Some thermophilic bacteria are growing even in acid foods such as fruit concentrates [27] and are encountered in process lines or orchard soils [28-30]. For example, the " $D$ value" of Acyclobacillus in concentrated lemon product $\left(50^{\circ}\right.$ brix) at $86^{\circ} \mathrm{C}$ may reach $69 \mathrm{~min}$ [31]. The fruit beverage industry applies a hot-filled-hold pasteurization process, where the product is held at $86^{\circ} \mathrm{C}-96^{\circ} \mathrm{C}$ for $\sim 2 \mathrm{~min}$. It is clear that this thermal treatment does not eliminate Acyclobacillus [29].

The majority of mold species present low heat resistance, having their vegetative structure (conidia and hyphae) easily destroyed by heat. However, some thermal resistant molds are reported in fruit products [32-34]: Byssochlamys nivea $\left(D_{85^{\circ} \mathrm{C}}\right.$ value $34.6 \mathrm{~min}, z$ value $6.4^{\circ} \mathrm{C}$ in strawberry pulp), Neosartorya fischeri $\left(D_{85^{\circ} \mathrm{C}}\right.$ value $19.6-29.5 \mathrm{~min}, z$ value $9^{\circ} \mathrm{C}$ in pineapple juice), and Talaromyces flavus $\left(D_{85^{\circ} \mathrm{C}}\right.$ value $3.3 \mathrm{~min}, z$ value $8.2^{\circ} \mathrm{C}$ in strawberry pulp)[32]. Beside bacterial problems, the presence of mycotoxins represents another hazard to food safety, and patulin [35] or ochratoxin A are the most important fruit juice-associated mycotoxins. The microbial quality and safety of fruit juices was reviewed recently [36]; the authors [36] highlight the necessity of more severe heat treatments for pasteurization of exotic fruits juices, which are less acid ( $\mathrm{pH} \mathrm{4.5-6.8)} \mathrm{than} \mathrm{the} \mathrm{classic}$ apples or citrus ( $\mathrm{pH}$ 1.8-4.5). In the context of an increasing demand in "freshness" and new tastes, the actual studies should consider the microbial, nutritional, and sensory aspects jointly in order to improve the quality and safety of fruit juices. 


\subsection{QUALITY ASSESSMENTS CONSIDERATIONS}

The International Organization of Standardization defines "quality" as "the degree to which a set of inherent characteristics fulfils to requirements." This definition is clearly in close relation to consumers who can appreciate the quality of a food product as bad, poor, good, or excellent. The consumer assessment is generally subjective, but the food producers and manufacturers have to identify measurable quality attributes and have to estimate their modifications during the food storage and processing. The quality attributes generally studied for fruits are texture, color, enzyme degradation, and the nutrients contents.

The thermal treatments of foods lead to substantial modifications of the final product qualities. Although microbial and chemical safety is prevalent during food processing, the sensory attributes are certainly the first criteria for acceptance and the major cause of rejection. The attributes such as color, shape, or texture are very important for both the first acceptance and regular purchasing of the food products. Most of the studies concerning the influence of thermal treatment on quality attributes are carried out in isothermal conditions, and the kinetics of quality parameters obey an irreversible first-order reaction kinetic similar to Equation 16.1.

As the food quality attribute levels are heterogeneous from a fruit to another, the fractional conversion model is frequently used [37] associated with a first-order kinetic reaction (Equation 16.7) in which $C(t)$ is the quality attribute level at a time $t$ and $C_{0}$ and $C_{\infty}$ are, respectively, the attribute level at the beginning of the treatment and after a long time. The quality attribute level after a long time $C_{\infty}$ is often temperature dependent and indicates an irreversible structure breakage of the fruit matrix. The fractional conversion model is given by

$$
\frac{C(t)-C_{\infty}}{C_{0}-C_{\infty}}=e^{-k(\vartheta) t}
$$

The kinetic parameters are greatly influenced by the temperature and the most frequently used theory in the area of food engineering is the following Arrhenius equation:

$$
\frac{k}{k_{r e f}}=\exp \left\lfloor\frac{E_{a}}{R}\left(\frac{1}{T_{r e f}}-\frac{1}{T}\right)\right\rfloor
$$

where $T$ is the absolute temperature, $R$ is the universal gas constant $\left(8.134 \mathrm{~J} \mathrm{~mol}^{-1} \mathrm{~K}^{-1}\right)$, and $E_{a}$ $\left(\mathrm{kJ} \mathrm{mol}^{-1}\right)$ is the activation energy.

It can be noted that the previously mentioned $z$ value for microorganism's destruction can be evaluated in terms of an activation energy. The activation energy of microorganism destruction varies from 8 to $15 \mathrm{~kJ} \mathrm{~mol}^{-1}$, and the quality loss activation energy varies between 30 and $100 \mathrm{~kJ} \mathrm{~mol}^{-1}$. Therefore, a high-temperature short-time (HTST) process can be applied to increase the product quality while ensure the microbial safety.

The quality attribute loss is also studied during the storage of canned foods, for example, vitamin $\mathrm{C}$ degradation in canned pineap $=$ lices [38] obeys a first-order kinetics reaction with

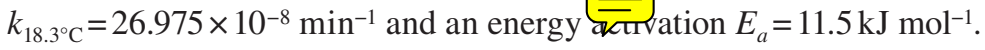

\subsection{APPLICATIONS OF THERMAL PROCESSING}

Thermal treatments are omnipresent in food processing: blanching, pasteurization, sterilization, cooking, drying, frying, microwave or radiofrequency or ohmic heating, etc. Moreover, a final food product is subjected to different heat treatments including the domestic cooking or cold storage. Thermal treatments are also used for disinfecting whole fruits such as mango [39] in warm water 
$\left(45^{\circ} \mathrm{C}\right)$ during $10-40 \mathrm{~min}$. In this chapter, we will overview the main thermal treatments of fruits: blanching and pasteurization/sterilization.

\subsubsection{BLANChing}

Blanching is a thermal treatment in hot water or steam aimed to inactivate oxidative enzymes naturally present in fruits and responsible for off-flavors, color change, and chemical reactions during the further processing steps and storage. This first thermal step is very important when the fruits are further processed. The influence of blanching on quality attributes [40] is generally evaluated together with the following process steps such as freezing, sterilizing, drying, and osmodehydration. This thermal step also helps to destroy microorganisms (bacteria, yeasts, and molds), prevent the flesh contamination when cutting [41], clean the fruits, brighten the color, and expel trapped air in the intercellular regions. The main enzymes affected by blanching are peroxidase, polyphenol oxidase, catalase, lipoxygenase, and chlorophylase; their thermal kinetic inactivation is documented [42].

Blanching is carried out by different means such as hot water, steam [43], high pressure, infrareddry blanching [44,45], ohmic [46], fluidized bed with steam, whirling bed with a mix of hot air and steam [47], individual quick blanching system, combined with ozone $[48,49]$. Hot-water blanching is by far the most popular and commercially adopted process for its simplicity and economic reasons. The microbial quality of the blanching water must also be observed because the high temperature could select thermophilic bacteria. The main problem of water blanching is the leaching of important nutrients such as vitamins and pigments.

Due to the thermal diffusion in food matrices, blanching efficiency greatly depends on the size and shapes of the fruits. The thermal product conductivity governs the heat transfer in the matrix, and in the case of unsteady state, the thermal diffusivity is introduced in the heat transfer equations. The thermal diffusivities of fruits [50] vary between $1 \times 10^{-7}$ and $1.8 \times 10^{-7} \mathrm{~m} \mathrm{~s}^{-2}$ : the heat transfers are 1000 times faster than the mass transfer of micronutrients in fruits. It is also important to note that as the thermal transfer time depends on the fruit pieces as the size at the power 2, size reduction is interesting in terms of heat and mass transfers.

\subsubsection{Pasteurization}

Pasteurization is a mild treatment aiming to inactivate most of the enzymes and to inhibit the vegetative microorganism's cells, while sterilization eliminates also the spores. As mentioned previously, the thermal treatment depends on the microbial contamination. In the case of low-pH fruit products, a pasteurization process (reaching $85^{\circ} \mathrm{C}$ at the coldest point) allows a long shelf-life at room temperature. Different time and temperature combinations can be used.

For fruit juices, in the traditional practice, the juices are heated up to $60^{\circ} \mathrm{C}-75^{\circ} \mathrm{C}$ for $30 \mathrm{~min}$, then filled at that temperature, closed and pasteurized at $84^{\circ} \mathrm{C}-88^{\circ} \mathrm{C}$ during $15-45 \mathrm{~min}$ depending of the size of the packaging. After this heat treatment, the products are cooled back to room temperature. High-temperature short-time pasteurization is conducted at higher temperatures $\left(>90^{\circ} \mathrm{C}\right)$ for shorter times. This can, for example, be carried out at $95^{\circ} \mathrm{C}-98^{\circ} \mathrm{C}$ for about $15-30 \mathrm{~s}$ for apple juice. Hot-fill-hold of containers $\geq 1 \mathrm{~L}$ with rapid closure gives temperatures $>85^{\circ} \mathrm{C}$ due to thermal inertia. Ultrahigh temperature (UHT) is also applicable to juices and commonly used in larger plants.

Before this pasteurization operation, the previous operations are washing/blanching, crushing, enzyme maceration $\left(40^{\circ} \mathrm{C}-50^{\circ} \mathrm{C} / 1-2 \mathrm{~h}\right)$, pressing, centrifugation or filtration, optional second enzyme treatment, and deaeration. For citrus and especially orange juices, specific extractors are used to avoid contamination of the juice with peels, and the stabilization treatment must be applied within a few minutes of extraction to avoid pectin methylesterase action.

The fruit products are also processed in a more or less viscous liquid form or in a combination of liquid and solid phases (purées, preserves, jams, etc.). These can be treated in continuous 
equipment. For purées, two processes are commonly differentiated by the respective order of the sieving and cooking phases: sieving before cooking for cold-break products or after cooking for hot-break products. They result in different colors, textures, and compositions due to the possibility of enzyme activity in the cold-break products.

The process line consists of a holding tank, a mill, a heating zone, a sieve, a holding zone (in principle for a few minutes, up to $0.5 \mathrm{~h}$ ), a pasteurization step followed by hot-fill or a cooling zone for aseptic packaging equipment. High temperatures are required during processing for fruit cooking and for adequate viscosities during pumping, so that additional heat treatments are limited. For example, for apple puree, a cooking time of $15 \mathrm{~min}$ at $85^{\circ} \mathrm{C}$, holding tanks at $50^{\circ} \mathrm{C}-85^{\circ} \mathrm{C}$, and a final pasteurization of $2-3 \mathrm{~min}$ at $90^{\circ} \mathrm{C}$ [51] then hot-fill can be sufficient to ensure stability at room temperature for months. Jams require higher temperatures for cooking and evaporation; thermal treatment under vacuum is preferred as it limits both temperature and product degradation during the concentration phase. However, temperatures must stay above pectin gelation, that is, $>70^{\circ} \mathrm{C}-90^{\circ} \mathrm{C}$, depending on the pectin grade.

The juices are frequently concentrated to be reused in fruit drinks. Concentration of juices is most commonly carried out by vacuum concentration, using efficient multieffect systems with recovery of volatiles. The volatiles are later used in juice reconstitution for aroma restoration. The evaporators operate at temperatures $<50^{\circ} \mathrm{C}$. Redilution of the concentrated juices entails an additional pasteurization of the final product. Nonthermal alternatives (osmotic evaporation and membrane distillation) are gaining interest due to their more limited effect on juice volatiles.

\subsubsection{Canned Food Products}

Among the different sterilization processes, the canned food process has been one of the most widely used methods of food preservation during the twentieth century for ensuring nutritional well-being of populations. The advantages of canned foods are determinant: relative low price, storage at room temperature, acceptable nutrient contents, easy to use, and varied contents. This process consists of heating hermetically sealed food containers (cans, plastic bottles and containers, and flexible pouches) in pressurized retorts and imposing a prescribed time-temperature history [52].

In the case of fruits containing trapped air such as apricot [53], peaches [54], or plums [55], an exhausting procedure during $5-10 \mathrm{~min}$ at $90^{\circ} \mathrm{C}$ in a steam chamber is used to remove the air.

The sterilization process is achieved in batch retorts, with the cans being or not agitated, or in continuous retorts in which the cans are agitated. In these retorts, the cans are heated by steam or pressurized water, maintained at a high temperature until the whole can content is subjected to the predetermined time-temperature history. Very roughly, $15 \%$ of the process thermal efficiency is achieved during the heating phase, $15 \%$ during the cooling phase, and the rest is achieved during the holding phase. The complete time treatment depends on the size of cans and the contained product.

There are different types of retorts. The craterless retort consists in a tank in which the cans fall in hot water after which the top hatch is closed and vapor is injected up to the desired temperature. The cans are immobile and when the thermal treatment is achieved, warm water is injected in the retort, and the bottom hatch is opened to let the cans fall in the discharge cooling canal. The filling, heating, warming, and discharging are automatically carried out.

The hydrostatic sterilizers are so named because steam temperature is controlled hydrostatically by the height of the water leg, and they have self-contained structure that is often partly built outdoors. The hydrostatic sterilizers are made up of four chambers: a hydrostatic bring-up leg, a sterilizing steam section, a hydrostatic bring-down leg, and a cooling section. The cans are conveyed continuously through the different chambers by a continuous chain link, and the residence is adjusted by the speed of the conveyers.

The continuous rotary sterilizers are horizontal (indoor) rotary retorts in which the cans are conveyed by a reel while they rotate around their own axis by different means. The residence time in the 
sterilizer is controlled by the rotating speed of the reel. The most common systems require at least three shells in series to heat under pressure, cool under pressure, and cool at atmospheric pressure. These retorts generally accommodate a specific can size and are not flexible.

There are different types of discontinuous retorts in which the cans are contained in large baskets rotating on their own axis at different speeds or shaken at high speeds.

During the thermal treatment, the temperature in the cans is measured with special devices such as thermocouples and is modeled as a function of the operating conditions such as agitation, rotation, and transport and the contents, that is, type of fruit pieces, and syrup concentration. The heat transfer between the can wall and the content is the limiting factor of the heat transmission; the motion such as rotation and vibrations of the cans enhance this heat transfer.

The bases of the thermal treatment calculations are well documented in several books (e.g., see Ref. [52]) and are out of the scope of this chapter.

The sterilization temperature/times for canned fruits are typically $100^{\circ} \mathrm{C} / 17-30 \mathrm{~min}$ for apricot, $93^{\circ} \mathrm{C}-95^{\circ} \mathrm{C} / 25-30 \mathrm{~min}$ for blueberry, $100^{\circ} \mathrm{C} / 20-350 \mathrm{~min}$ or $116^{\circ} \mathrm{C} / 14-18 \mathrm{~min}$ for peaches, and $100^{\circ} \mathrm{C} / 12 \mathrm{~min}$ for plums.

For high-quality orange juices, it is proposed to centrifuge the raw product and to apply two different thermal treatments for the pulp $\left(85^{\circ} \mathrm{C} / 15 \mathrm{~s}\right)$ to inactivate the pectin methylesterase and for the low pulp juice $\left(65^{\circ} \mathrm{C} / 15 \mathrm{~s}\right)$ to inactivate the microorganisms and then to blend these two products [56].

\subsubsection{Continuous Sterilization and Aseptic Processing}

In this technology, the product is convoyed by a volumetric pump through heat exchanger (D) efly described earlier. For fruit juices, the applied process is $100^{\circ} \mathrm{C}-110^{\circ} \mathrm{C}$ for $0.5-1.5 \mathrm{~min}$.

W D previously mentioned the problem of the particles moving in the suspending fluid. Another problem, actually not well solved, concerns the local accumulation of particles in elbows, for example, leading to plugging the process line. The treatment time is adjusted for the fastest particle in the line and the product must be poured in presterilized containers in an aseptic environment before the containers are hermetically sealed. The main problems are often encountered in the cooling zone because the product viscosity can become very high and pasty.

This technology is very elegant and energy saving but is difficult to manage, especially in aseptic filling when the product contains particles and fibers. Along with the classical tubular or scraped surface heat exchangers used for pasty or particle content fluids, new technologies such as ohmic [57] or radio frequency [58] are available for the industry. The main advantage of these techniques consists in heating in the mass both suspending fluid and particles at the same time, if their electric conductivities or their dielectric losses are almost the same, thus enhancing the quality of the final products.

\subsection{QUALITY ATTRIBUTE MODIFICATIONS DURING THERMAL PROCESSING OF FRUITS}

\subsubsection{TeXture}

Texture is a very important quality attribute and is closely linked to sensory analysis $[59,60]$. The texture measurements of different food products by objective, subjective, and imitative tests are well described in a reference book [61]. The most used tests for fruits are puncture, double compression [7], texture profile analysis [62], Kramer cell [63], and three-point bending test with notch [64]. These tests are performed on whole fruits or pieces (slices, cubes, sticks, and cylinders).

Recently, new approaches have been developed to quantify the texture (or shape) changes during food processing. The crispiness (the number, frequency, and shape of peaks in the jagged part of a force-deformation curve) frequently studied for extruded or brittle food products [65] 
was applied to cucumbers [66] and apples [67]. Computer image analysis with adapted software is applied to food quality [68], including the study on damaged banana and apple tissues [69-72]. Microscopic observations give also pertinent information on the fruit tissues, for example, affected by pretreatments and freezing [73,74]. The micromechanics [75] associated with the image analysis is also a promising technique to evaluate fruit textures (apple tissue [76]) and their variations during thermal (or other) treatments. Acoustic methods are also used for the assessment of apple texture $[67,77,78]$.

The mechanisms of texture evolution during heat processing are closely related to pectin degradation [79]. They therefore depend on the time-temperature history [80], on intrinsic parameters of the fruit tissue such as pectin content, degree of methylation, and activity of pectin degrading enzymes, and on parameters that can be adjusted during processing such as $\mathrm{pH}$, the presence of cations, and notably calcium salts $[81,82]$.

Fresh fruit texture is determined by the interaction between turgor pressure of the cells and the resistance of the cell walls that surrounds the cells. The cell walls have two functions in the living fruit: the middle lamella is responsible for cell-to-cell adhesion, and the primary cell walls for limiting cell expansion. During heat treatment, the first phenomenon that leads to texture loss is the loss of turgor pressure upon membrane destabilization. Two successive mechanisms then determine texture evolution. At low temperatures $\left(55^{\circ} \mathrm{C}-75^{\circ} \mathrm{C}\right)$, pectin methylesterases are activated; these enzymes have high optimal temperatures and can be remarkably heat resistant [83-85]. Pectin meth $\equiv$ erases hydrolyze the methyl esters on the carboxylic acid at C6 of galacturonic acid, realiz ing methanol and free carboxyl groups. Subsequent pectin demethylation will contribute to a firmer texture by minimizing latter susceptibility to $\beta$-elimination and by enabling the formation of additional calcium cross-links. At higher temperatures, the chemical mechanisms that lead to pectin cleavage take their turn. Their efficiency will depend on pectin degree of methylation and $\mathrm{pH}$. At low pHs $(<4)$, pectin cleavage is predominantly by hydrolysis, irrespective of degree of methylation. At slightly acidic to neutral pHs, $\beta$-elimination, a mechanism specific to methylated pectins, determines pectin degradation. $\beta$-elimination demands the presence of a methylated uronic acid: highly methylated pectins are highly susceptible to $\beta$-elimination while pectic acid, totally demethylated, is impervious to this cleavage $[79,81,86]$. These mechanisms and their succession are shown in Figure 16.2.

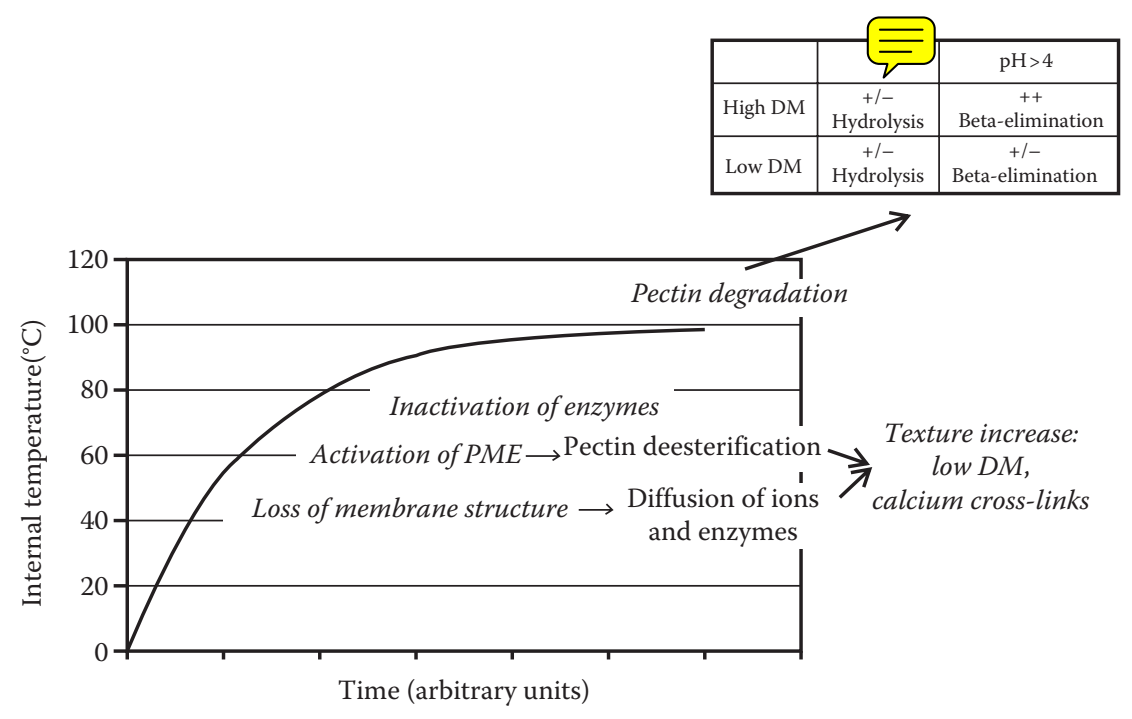

FIGURE 16.2 The two successive mechanisms involved in the vegetable texture evolution during thermal treatment. 
There is therefore a potential for manipulation of texture through low-temperature blanching, enabling pectin methylesterase activation, and calcium addition [87]. This process is known as lowtemperature long-time (LTLT) blanching, which results in firmer products through in situ activation of endogenous pectin methylesterase [88].

\subsubsection{Thermal Softening of Fruits}

In terms of reaction kinetics, the thermal softening of fruits is less documented than for vegetables [89]. Some examples of thermal softening of fruits by heat treatments are presented in Table 16.1. The $D$ values greatly depend on the product and its variety, for canned apricots [90,93], cooked apricots [101], bananas [100], banana and plantain [92], or apples [7]. For the two later examples, the texture classification before and after heat treatments are not the same, indicating that it is not possible to predict the final product texture from texture measurements on the raw materials. Generally, the texture decrease is important $\left(60^{\circ} \mathrm{C}-80^{\circ} \mathrm{C}\right)$ and rapid $(10-20 \mathrm{~min})$ when heating at the pasteurization temperatures and less important for milder treatment temperatures [90,95]. The sterilization of canned banana is also studied [97].

The same results are obtained when ohmic heating peaches slices at different frequencies [102]. When the data are available, the energy activation $E_{a}$ of the first-order kinetic reaction (about $100 \mathrm{~kJ} \mathrm{~mol}^{-1}$ ) is similar to the thermal softening of vegetables.

\section{TABLE 16.1}

\section{AQ2 Examples of the Thermal Softening of Fruits in Different Operating Conditions}

\begin{tabular}{|c|c|c|c|}
\hline Fruits & Treatment & Main Results & Reference \\
\hline Apricots & Hot water $70^{\circ} \mathrm{C}-90^{\circ} \mathrm{C}$ & $D_{90^{\circ} \mathrm{C}} 2 \min E_{a} 96.6 \mathrm{~kJ} \mathrm{~mol}^{-1}$ & {$[90]$} \\
\hline Plums (different ripeness) & Canned with and without $\mathrm{Ca}^{++}$ & Better texture when added $\mathrm{Ca}^{++}$ & {$[91]$} \\
\hline Plantain banana & Heating $60^{\circ} \mathrm{C}-100^{\circ} \mathrm{C} 0-30 \mathrm{~min}$ & $\begin{array}{l}\text { Rapid texture decrease during the } \\
\text { first } 10 \mathrm{~min}\end{array}$ & [92] \\
\hline Apricots & Canned $82^{\circ} \mathrm{C}-95^{\circ} \mathrm{C}$ & $D_{90^{\circ} \mathrm{C}} 17 \mathrm{~min} E_{a} 116.5 \mathrm{~kJ} \mathrm{~mol}^{-1}$ & {$[93]$} \\
\hline Apple slice & PEF and heat treatment & $\begin{array}{l}\text { PEF + heat treatment disintegrates } \\
\text { the tissue texture to the state of a } \\
\text { freeze-thawed tissue }\end{array}$ & {$[94]$} \\
\hline Guava & Processed in syrup $60^{\circ} \mathrm{C}-90^{\circ} \mathrm{C}, 1 \mathrm{~h}$ & $\begin{array}{l}\text { Considerable softening at } 90^{\circ} \mathrm{C} \\
\text { unlike milder temperature } \\
\text { processing }\end{array}$ & {$[95]$} \\
\hline Kiwi slices & $\begin{array}{l}\text { Pretreatment } 25^{\circ} \mathrm{C}-50^{\circ} \mathrm{C} 26-74 \mathrm{~min} \\
\text { before minimally processing }\end{array}$ & $\begin{array}{l}\text { Better texture with pretreatment if } \\
\text { fruit is ripe }\end{array}$ & {$[96]$} \\
\hline Canned bananas & $121^{\circ} \mathrm{C} 25 \mathrm{~min}$, storage 135 days & $\begin{array}{l}\text { Texture: Rasthali variety }> \\
\text { Poowan }>\text { red banana }\end{array}$ & {$[97]$} \\
\hline Apples different cultivars & Vacuum pasteurization $95^{\circ} \mathrm{C} 25 \mathrm{~min}$ & $\begin{array}{l}\text { Texture classification of the } \\
\text { cultivars is different before and } \\
\text { after treatment processing }\end{array}$ & [7] \\
\hline Peach slices & Heating $50^{\circ} \mathrm{C}, 10 \mathrm{~min}$ before slicing & better texture when heated & {$[98]$} \\
\hline Canned pears & $\begin{array}{l}\text { Heating with } 0 \%-3 \% \mathrm{CaCl}_{2} \text { in } 40 \% \\
\text { syrup }\end{array}$ & $\begin{array}{l}\mathrm{CaCl}_{2} \text { enhances texture irrespective } \\
\text { of ripeness stage }\end{array}$ & [99] \\
\hline Banana & Heating at $96.5^{\circ} \mathrm{C} 0-120 \mathrm{~min}$ & $D_{90^{\circ} \mathrm{C}} 4-10.4 \mathrm{~min}$ & {$[100]$} \\
\hline Apricots different cultivars & Heating $100^{\circ} \mathrm{C} 10 \mathrm{~min}$ & $\begin{array}{l}\text { Texture losses are different for the } \\
\text { different apricot varieties }\end{array}$ & {$[6]$} \\
\hline
\end{tabular}


The texture of canned product is a crucial proble $\equiv \mathrm{d}$ a very often used solution for firmer products is the immersion in $\mathrm{CaCl}_{2}$ solution (about 100 [91]. Mild heat treatment $\left(50^{\circ} \mathrm{C}\right)$ was used to enhance the texture of minimally processed kiwis [96] or sliced peaches [98].

Thermal treatment, combined with other physical treatment, is used for partially disintegrating the texture, thus enhancing the juice extraction for apple (e.g., with pulsed electric fields) [94] and other materials [103]. Heat treatment (boiling during $15 \mathrm{~min}$ ) is also used before candying plums (up to 2 months in 60-65 and 75 brix sugar syrups) [104]. In addition, a vacuum impregnation was also tested at mild temperature $\left(30^{\circ} \mathrm{C}\right)$ for candying pineapple [105].

\subsubsection{Rheological Behavior of Purees and Compotes}

The fruit juices are generally Newtonian and poorly viscous (less than seven times the water viscosity) [106-109]. The concentrates are more viscous and exhibit a shear thinning pseudoplastic behavior [107,108,110-114]. Adding fibers drastically thickens the fruit juices [115-117], leading to highly viscous fluid exhibiting a strong yield stress.

Fruits are often prepared as semiliquid purées and compotes, which have a long storage life and are convenient. These pasty products exhibit a yield stress $\tau_{0}$, a force (or stress) level required for flowing, which is a very important quality parameter for spoonability, spreadability, and sensory evaluation of such food products. The flow behavior is modeled with the following Herschel Bulkley equation [117,118] determined with rheometers. This approach is applied for apple sauces [51] or different fruit purees [119]:

$$
\tau=\tau_{0}+K \dot{\gamma}^{n}
$$

Another interesting rheological property is the thixotropy, typically the ketchup behavior: when shaking the container, the product becomes liquid and when staying at rest (or less sheared), the yield stress is rebuilt [120]. Some purées and fruit concentrates exhibit such a rheological behavior $[110,111,113,114,121-126]$.

The industrial rheology determination of pasty products is often made with a Bostwick consistometer [127,128], this test does not give precise rheological data but is very pertinent for formulating pasty products and control during and after processing.

\subsubsection{Juice Cloud Stability}

Pectin methylesterases are of particular interest in fruit juice processing as they are determinant for cloud stability and highly thermo (and baro) resistant, that is, they are more stable than the bacterias and yeasts present. Cloud in fruit juices are due to the presence of dissolved pectin colloids (ca. $0.1 \mu \mathrm{m})$ and small particles $(0.5-10 \mu \mathrm{m})$. Cloud stability is linked to electrostatic repulsions between these particles, where negatively charged pectins surround a protein nucleus (itself positively charged at the juice $\mathrm{pH}$ ). Pectin methylesterases in fruit juices lead to cloud destabilization [129] by the formation of sequences with consecutive free galacturonic acids on the pectin main chain, leading to a very high calcium reactivity [130] and pectin precipitation. Pectin methylesterases have been particularly studied for citrus juices and especially orange, which contains high pectin methylesterases and the juice of which should have stable cloud [129-137]. Heating of orange juices at $90^{\circ} \mathrm{C}$ for $1 \mathrm{~min}$ is sufficient to ensure their colloidal stability, but this thermal treatment must take place very rapidly after expression. Pectin methylesterases are generally deactivated following firstorder kinetics; however, isoforms with differing thermal stability are present in orange, leading to biphasic kinetics $[83,135]$. The $z$ values for thermolabile and thermostable orange pectin methylesterases are $10.8^{\circ} \mathrm{C}$ and $6.5^{\circ} \mathrm{C}$ for orange pulp [138], while the $z$ values for microwave-heated orange juice are $31.1^{\circ} \mathrm{C}\left(D_{60^{\circ} \mathrm{C}}=1240 \mathrm{~s}\right)$ and $17.6^{\circ} \mathrm{C}\left(D_{60^{\circ} \mathrm{C}}=154 \mathrm{~s}\right)$ [139] with activations energies of $299 \mathrm{~kJ}$ $\mathrm{mol}^{-1}\left(k_{73.5^{\circ} \mathrm{C}}=8.5 \mathrm{~min}^{-1}\right)$ and $532 \mathrm{~kJ} \mathrm{~mol}^{-1}\left(k_{73.5^{\circ} \mathrm{C}}=0.003 \mathrm{~min}^{-1}\right)[140]$. The relative proportions of the thermostable and thermolabile isoforms may vary, but the thermostable form is always the lowest, 
often between $5 \%$ and $10 \%$ [85,131,133,135,138,139]. It is generally considered that inactivation of the thermolabile form is sufficient for acceptable cloud stability. Efficiency of inactivation also varies with $\mathrm{pH}$, with the more acidic conditions leading to faster inactivation: for thermostable orange pectin methylesterases $D_{90{ }^{\circ} \mathrm{C}}=33 \mathrm{~s}$ at $\mathrm{pH} 3.6$ but $256 \mathrm{~s}$ at $\mathrm{pH} 4.1$ [137]. Thermal stability of pectin methylesterase appears to be higher for soluble enzymes in the juice that in the pulp [133] but that was not related to isoforms distribution.

Other fruits also present pectin methylesterases with high thermal stabilities, though few studies report $z$ values or activation energies. One of the pectin methylesterase from acerola kept its activity after $1 \mathrm{~h}$ at $98^{\circ} \mathrm{C}$ [141]. Apple pectin methylesterase presents $z$ value of $10.1^{\circ} \mathrm{C}$ (with $\left.D_{50^{\circ} \mathrm{C}}=7.4 \mathrm{~min}\right)$ [84]. Activation energies were for banana $E_{a}=279 \mathrm{~kJ} \mathrm{~mol}^{-1}\left(k_{75^{\circ} \mathrm{C}}=0.55 \mathrm{~min}^{-1}\right)[140]$, for plum (biphasic with about $60 \%$ thermolabile enzyme) $E_{a}=274 \mathrm{~kJ} \mathrm{~mol}^{-1}\left(k_{60^{\circ} \mathrm{C}}=0.106 \mathrm{~min}^{-1}\right)$ and $E_{a}=354 \mathrm{~kJ} \mathrm{~mol}^{-1}\left(k_{60}{ }^{\circ} \mathrm{C}=0.008 \mathrm{~min}^{-1}\right)$ [142], and for grapefruit thermostable pectin methylesterase $E_{a}=329 \mathrm{~kJ} \mathrm{~mol}^{-1}\left(k_{60}{ }^{\circ} \mathrm{C}=0.189 \mathrm{~min}^{-1}\right)$ [143]. Influence of physical-chemical conditions was reported, with stability at $\mathrm{pH} 7>4$ for plum [142] and optimal stability at $\mathrm{pH} 7$ and high ionic strength for grapefruit [143]. Remarkably, high pressure and temperatures have an antagonistic effect in pectin methylesterase inactivation [83].

\subsubsection{Color and Image Analysis}

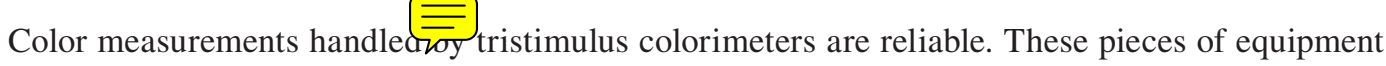
give the color in different units, with the most used with food products being the $L^{*}, a^{*}, b^{*}$ color space coordinates [144] or the quasi similar $L, a, b$ system. Lightness value, $L^{*}$ indicates how dark/light the sample is (varying from 0 - black to 100 - white), $a^{*}$ is the measure of greenness/ redness (varying from -60 to +60 ), and $b^{*}$ is the measure of blueness/yellowness (varying from -60 to +60 ). The polar coordinate chroma or saturation $C^{*}$ is an indication of how dull/vivid the product is (ranging from 0 to 60 ), which can be calculated from $a^{*}$ and $b^{*}$ Cartesian coordinates by the following equation:

$$
C^{*}=\sqrt{a^{* 2}+b^{* 2}}
$$

The total color difference (TCD*) is a parameter considered for the overall color difference evaluation between the reference sample (initial product or a reference ceramic plate) and the processed one. Differences in visual color can be classified based on TCD* as follows: not noticeable $(0-0.5)$, slightly noticeable (0.5-1.5), noticeable (1.5-3.0), well visible (3.0-6.0), and great difference (6.0-12.0).

$$
\mathrm{TCD}^{*}=\sqrt{\left(L_{0}^{*}-L^{*}\right)^{2}+\left(a_{0}^{*}-a^{*}\right)^{2}+\left(b_{0}^{*}-b^{*}\right)^{2}}
$$

Other parameters are calculated from $L^{*}, a^{*}$, and $b^{*}$. The hue angle, that is, $h^{*}=\tan ^{-1}\left(b^{*} / a^{*}\right)$, is frequently used to characterize reddish or yellowish color. The use of $a^{*} / b^{*}$ cannot be advocated as it reflects a faulty understanding of the color coordinates.

The browning index, defined as absorbance at $420 \mathrm{~nm}$ of a centrifuged and filtered juice, is also frequently used to detect the nonenzymatic browning of fruits matrices or juices.

Examples of the influence of heat treatments on fruit jams and juices are presented in Table 16.2. In Table 16.2, only TCD (or TCD*) is mentioned, which seems to be a well-recognized quality index. The most recent publications compare the thermal treatment with nonconventional ones [149,150,158-160]. The color loss kinetic is modeled with the aforementioned models [145-148,151-154], and the energy activation varies between 30 and $120 \mathrm{~kJ} \mathrm{~mol}^{-1}$ with an exception for the strawberry juice in which the group $L^{*} \cdot a^{*} / b^{*}$ was used [154]. 


\begin{tabular}{|c|c|c|c|c|}
\hline Products & Thermal Treatment & TCD or TCD* & Comments & Reference \\
\hline Peach puree & $\begin{array}{l}10^{\circ} \mathrm{C}-135^{\circ} \mathrm{C} \text { up to } \\
160 \mathrm{~min}\end{array}$ & & $\begin{array}{l}\text { Fractional first-order kinetic } \\
\text { model } E_{a} 119 \mathrm{~kJ} \mathrm{~mol}^{-1}\end{array}$ & {$[145]$} \\
\hline Cupuacu puree & $\begin{array}{l}80^{\circ} \mathrm{C}-115^{\circ} \mathrm{C} \text { up to } \\
120 \mathrm{~min}\end{array}$ & $\begin{array}{l}0-680^{\circ} \mathrm{C} ; 0-18 \\
115^{\circ} \mathrm{C}\end{array}$ & $\begin{array}{l}\text { Fractional first-order kinetic } \\
\text { model } E_{a} 36 \mathrm{~kJ} \mathrm{~mol}^{-1}\end{array}$ & [146] \\
\hline Peach puree & $\begin{array}{l}80^{\circ} \mathrm{C}-98^{\circ} \mathrm{C} \text { up to } \\
500 \mathrm{~min}\end{array}$ & $0-480^{\circ} \mathrm{C} ; 0-1898^{\circ} \mathrm{C}$ & $\begin{array}{l}\text { Combined zeroth- and first-order } \\
\text { kinetic model } E_{a} 82 \mathrm{~kJ} \mathrm{~mol}^{-1}\end{array}$ & [147] \\
\hline Pineapple puree & $\begin{array}{l}70^{\circ} \mathrm{C}-110^{\circ} \mathrm{C} \text { up to } \\
500 \mathrm{~min}\end{array}$ & $\begin{array}{l}0-20 \text {, increase with } \\
\text { temperature }\end{array}$ & $\begin{array}{l}\text { Zeroth-order kinetic } E_{a} 83.7 \mathrm{~kJ} \\
\mathrm{~mol}^{-1} 70^{\circ} \mathrm{C}-90^{\circ} \mathrm{C} \\
E_{a} 94.4 \mathrm{~kJ} \mathrm{~mol}^{-1} 90^{\circ} \mathrm{C}-110^{\circ} \mathrm{C}\end{array}$ & [148] \\
\hline $\begin{array}{l}\text { Strawberry and } \\
\text { blackberry puree }\end{array}$ & $70^{\circ} \mathrm{C}, 2 \mathrm{~min}$ & $\begin{array}{l}\text { Strawberry } 5.67 \\
\text { Blackberry } 3.17\end{array}$ & $\begin{array}{l}\text { Comparison thermal/high } \\
\text { pressure }\end{array}$ & [149] \\
\hline Nectarine puree & $85^{\circ} \mathrm{C}, 5 \mathrm{~min}$ & $\begin{array}{l}\text { Treated/untreated: } 2.5 \\
\text { Treated/60 storage } \\
\text { days: } 7.7\end{array}$ & $\begin{array}{l}\text { Comparison thermal/high } \\
\text { pressure }\end{array}$ & {$[150]$} \\
\hline Pineapple juice & $55^{\circ} \mathrm{C}-95^{\circ} \mathrm{C}, 80 \mathrm{~min}$ & $\begin{array}{l}0-0.755^{\circ} \mathrm{C} ; 0-1.8 \\
65^{\circ} \mathrm{C} ; 0-2.275^{\circ} \mathrm{C} \\
0-385^{\circ} \mathrm{C} ; 0-495^{\circ} \mathrm{C}\end{array}$ & $\begin{array}{l}\text { Combined kinetic model, } E_{a} \\
47.3 \mathrm{~kJ} \mathrm{~mol}^{-1}\end{array}$ & {$[151]$} \\
\hline $\begin{array}{l}\text { Yellow-orange } \\
\text { cactus pear juice }\end{array}$ & $\begin{array}{l}75^{\circ} \mathrm{C}, 85^{\circ} \mathrm{C}, 95^{\circ} \mathrm{C} \\
60 \mathrm{~min}\end{array}$ & $\begin{array}{l}0-1075^{\circ} \mathrm{C} ; 0-18 \\
85^{\circ} \mathrm{C} ; 0-3095^{\circ} \mathrm{C}\end{array}$ & $\begin{array}{l}\text { Addition of } 0.1 \% \text { isoascorbic } \\
\text { acid prior to heating minimized } \\
\text { color alteration }\end{array}$ & {$[152]$} \\
\hline $\begin{array}{l}\text { Purple pitaya } \\
\text { juice }\end{array}$ & $85^{\circ} \mathrm{C} 1 \mathrm{~h}, \mathrm{pH} 4$ and 6 & $C^{\mathrm{a}}$ and $h^{\mathrm{a}}$ & $\begin{array}{l}\text { Betacyanins in purple pitaya } \\
\text { juice is stabilized by the } \\
\text { addition of ascorbic, } \\
\text { isoascorbic, citric acids }\end{array}$ & {$[153]$} \\
\hline Strawberry juices & $\begin{array}{l}100^{\circ} \mathrm{C}-140^{\circ} \mathrm{C} \\
0-120 \mathrm{~min}\end{array}$ & $\begin{array}{l}\left(L^{*} a^{*} / b^{*}\right) \text { parameter, } \\
\text { kinetic fractional } \\
\text { model }\end{array}$ & $\begin{array}{l}E_{a} 183 \text { at } \mathrm{pH} 2.5,168 \text { at } \mathrm{pH} 3.7 \\
86 \text { at } \mathrm{pH} 5\left(\mathrm{~kJ} \mathrm{~mol}^{-1}\right)\end{array}$ & {$[154]$} \\
\hline Apple juice & $\begin{array}{l}\mathrm{HTST} 73^{\circ} \mathrm{C}, 80^{\circ} \mathrm{C} \\
83^{\circ} \mathrm{C} 27 \mathrm{~s}\end{array}$ & 1.3 & & \\
\hline $\begin{array}{l}\text { Cashew apple } \\
\text { juice }\end{array}$ & $\begin{array}{l}88^{\circ} \mathrm{C}, 100^{\circ} \mathrm{C}, 111^{\circ} \mathrm{C}, \\
121^{\circ} \mathrm{C}\end{array}$ & $0-15$ & $\begin{array}{l}\text { Kinetic modeled with an } \\
\text { exponential model }\end{array}$ & {$[155]$} \\
\hline $\begin{array}{l}\text { Cashew apple } \\
\text { model juice }\end{array}$ & $60^{\circ} \mathrm{C}, 90^{\circ} \mathrm{C}$ & $0-6$ & $\begin{array}{l}\text { Kinetic modeled with a biphasic } \\
\text { model }\end{array}$ & {$[156]$} \\
\hline Elderberry juice & $95^{\circ} \mathrm{C}, 0-4 \mathrm{~h}$ & $0-18$ & $\begin{array}{l}\text { Color differences in strawberry } \\
\text { and elderberry juices when } \\
\text { ascorbic acid was added }\end{array}$ & {$[157]$} \\
\hline Strawberry juice & & $0-14$ & & \\
\hline Watermelon juice & $\begin{array}{l}\text { Thermosonication } \\
25^{\circ} \mathrm{C}-45^{\circ} \mathrm{C} \text {, amplitude } \\
24.4-60.1 \mu \mathrm{m}\end{array}$ & $4.5-5.54$ & $\begin{array}{l}\text { Effect of process parameters on } \\
\text { quality indices modeled with a } \\
\text { second-order polynomial }\end{array}$ & {$[158]$} \\
\hline Watermelon juice & $60^{\circ} \mathrm{C}, 5-60 \mathrm{~min}$ & $6.94-5.87$ & $\begin{array}{l}\text { Comparison of thermal, } \\
\text { ultraviolet-c, and high-pressure } \\
\text { treatments }\end{array}$ & [159] \\
\hline Mango nectar & $60^{\circ} \mathrm{C}-85^{\circ} \mathrm{C}, 10-20 \mathrm{~min}$ & $\begin{array}{l}5.8 \text { at optimal } \\
\text { conditions }\end{array}$ & $\begin{array}{l}\text { High-pressure } \\
\text { homogenization + heat shock }\end{array}$ & {$[160]$} \\
\hline
\end{tabular}


Color degradations of fruits $[153,156,157]$ are clearly due to thermal degradation of pigments, and the reaction kinetics of these food components are summarized in a reference book [38] for anthocyanins, betalains, and carotenoids. The reaction kinetic modeling is based on the fraction conversion model associated with a first-order kinetic reaction. The reaction kinetic constants are well documented $[38,89]$ for different operating conditions and in different fruit matrices. The color variation kinetics is quite similar to that of pigments degradation.

Some other analyses such as near infrared (NIR) spectroscopy, middle infrared (MIR) spectroscopy [162], or hyperspectral imaging [163,164], are performed for inspecting or grading fruits and vegetables but are rarely used for determining the impact of thermal processing [165] on their quality attributes.

\subsubsection{Aroma Modification}

Two types of products must be distinguished when dealing with impact of thermal treatments on fruit juice aromas: the juices produced from concentrates and the more lightly heated not-fromconcentrate juices. In juice concentration, normally, volatiles are recovered and concentrated for later addition back to the concentrated products. Therefore, incomplete restoration will result in the loss of volatiles, as did the former practice of mixing concentrate (without recovered volatiles) with single strength juices.

A recent review summarizes the effects of heat treatments on orange juices [9], indicating that juice volatiles are impacted by even high-temperature short-time treatments due to the loss of more volatile molecules. However, this is not sufficient for detection of aroma modification by a sensory analysis. Typical cooked off-tastes are only perceived by consumers in juices from concentrates, which are subjected to concentration then pasteurization after redilution. Juices from concentrates are depleted in the more volatile molecules but contain more sulfur-containing volatiles because of thermal degradation of amino acids.

Ohmic heating of freshly squeezed orange juice resulted in slightly higher retention of limonene, myrcene, octanal, and decanal than conventional pasteurization (about $60 \%$ for all four compounds) [134]. In apple juice, conventional evaporation resulted in the loss of $>95 \%$ of trans-2-hexenal [166]. Apple juices not from concentrate were dominated by fruity, sweet aromatics, while apple juices from concentrate were assessed as more green, fresh, and having a shampoo-like smell [10].

\subsubsection{Nutritional Impact of Fruit Heat Processing}

This section will focus on the micronutrients for which fruits contribute significantly to diet. These are primarily vitamin $\mathrm{C}$ and provitamin $\mathrm{A}$ carotenoids ( $\beta-, \alpha-$, and $\gamma$-carotene and $\beta$-cryptoxanthin). Fruits also contain polyphenols, which will be briefly mentioned here, as polyphenol oxidation is a factor of ascorbic acid degradation and enzymatic browning. These compounds have very different sensitivities to heat-treatment, and these sensitivities are modulated differently by physicochemical conditions, as summarized in Table 16.3.

\subsubsection{Vitamin C}

Vitamin $\mathrm{C}$ is present in fruits, sometimes at high concentrations as in black currant, kiwi, oranges, and lemons. It is also often added during processing to prevent enzymatic browning, in particular in apple, banana, and small red fruits. Though vitamin $\mathrm{C}$ probably has been the most studied vitamin in terms of loss during heat treatments, there are still gaps in the understanding (and therefore modeling) of its loss. Vitamin C is composed of two compounds, both of which carry the vitaminic property: ascorbic acid is the reduced form of vitamin $\mathrm{C}$ and dehydroascorbic acid is its oxidized form. Fruits may contain both forms, with ratios that vary depending on the species, the physiological state, etc. 


\section{TABLE 16.3}

Main Factors of Loss and Relative Stability of Microconstituents in Fruits

\begin{tabular}{|c|c|c|c|c|c|}
\hline & $\begin{array}{l}\text { Susceptible } \\
\text { to Oxidation }\end{array}$ & $\begin{array}{l}\text { Other Chemical } \\
\text { Degradation } \\
\text { Mechanism }\end{array}$ & $\begin{array}{l}\text { Highly } \\
\text { Soluble } \\
\text { (Leaching) }\end{array}$ & $\begin{array}{l}\text { Concentrated } \\
\text { in Outer Parts }\end{array}$ & $\begin{array}{l}\text { Presence of } \\
\text { Enzymes }\end{array}$ \\
\hline Vitamin C & $++($ ascorbate $)$ & ++ (dehydroascorbate) & + & + & + (polyphenoloxidase) \\
\hline Vitamin B9 & $?$ & + & ++ & & \\
\hline Carotenoids & $+/-$ & +/- (isomerization) & 0 & + & \\
\hline Dietary fibers & 0 & $\begin{array}{l}+/-(\text { conversion to } \\
\text { soluble fibers })\end{array}$ & 0 & + & \\
\hline Polyphenols & + & 0 & $+1-$ & ++ & + (polyphenoloxidase) \\
\hline
\end{tabular}

These molecules have different susceptibilities to oxidation and thermal degradation: ascorbic acid can be oxidized easily and is in particular converted to dehydroascorbic acid by coupled oxidation-reduction with the quinones of polyphenols. Oxidation of polyphenols (by polyphenoloxidase or laccase prior to heat treatment, or by autoxidation catalyzed by metals after heat treatment) thus leads to loss of ascorbic acid. Dehydroascorbic acid can be further hydrolyzed to 2,3-diketoglutaric acid, which follows the sugar degradation reaction chain [167]. Of the two moieties, ascorbic acid is thus highly susceptible to degradation by oxidation (but very stable in anaerobic conditions), while dehydroascorbic acid is susceptible to heat degradation by Strecker degradation independently of oxygen concentration [168]. The requirement for oxygen in conversion of ascorbic acid to dehydroascorbic acid explains why vitamin $\mathrm{C}$ degradation can deviate from the first order [169]. Oxygen solubility in water at $20^{\circ} \mathrm{C}$ is of $9 \mathrm{mg} \mathrm{L}^{-1}$, that is, $0.28 \mathrm{mmol} \mathrm{L}^{-1}$ (oxygen solubility decreases with ${ }^{\circ}$ Brix [170]). This would be sufficient to oxidize $100 \mathrm{mg} \mathrm{L}^{-1}$ of ascorbic acid. However, concentrations of ascorbic acid close to $0.5 \mathrm{~g} \mathrm{~L}^{-1}$ are found in citrus juices or added to cloudy apple juices. Oxygen can be a limiting reagent, especially in hermetically sealed vessels or in closed process loops. Once the pool of dissolved oxygen is exhausted, ascorbic acid degradation stops or at least becomes much slower as it is relatively resistant to Strecker degradation. However, even in anaerobic condition, all dehydroascorbic will disappear in a relatively short time due to hydrolysis and Strecker degradation. This dual mechanism explains why nonlinear models can often better predict vitamin C loss [171], and also why deaeration is a major factor for juice quality. Two reactions with three reaction rate constants are thus needed to adequately describe ascorbic acid degradation in aerobic conditions [168]:

$$
\begin{gathered}
\mathrm{AA}+\frac{1}{2} \mathrm{O}_{2} \stackrel{K 1, K 2}{\longrightarrow} \mathrm{DHA}+\mathrm{H}_{2} \mathrm{O} \\
\mathrm{DHA}+\mathrm{H}_{2} \mathrm{O} \stackrel{K 3}{\longrightarrow} \mathrm{DKG}
\end{gathered}
$$

where

AA is ascorbic acid

DHA is dehydroascorbic acid

DKG is 2,3-diketoglutaric acid

$K 1$ is the reaction rate constant for ascorbic acid oxidation (apparent rate constant as oxygen concentration is not explicitly taken into account)

$K 2$ is the reconversion of DHA to ascorbic acid

$K 3$ is the subsequent hydrolysis of DHA 
In the presence of oxygen and absence of reducing agent, oxidation of ascorbic acid is much faster than reduction of dehydroascorbic acid. Serpen and Gökmen [172] reported a half-life of $3.21 \mathrm{~h}$ (decreased in the presence of $\mathrm{Fe}^{3+}$, increased by cysteine, a reducing agent) for a solution of ascorbic acid in pure water held at $90^{\circ} \mathrm{C}$. They calculated the apparent reaction rate constants as $K 1=0.218 \mathrm{~h}^{-1}$, $K 2=0.24910^{-8} \mathrm{~h}^{-1}$, and $K 3=0.218 \mathrm{~h}^{-1}$.

However, few studies take into account the dual nature of vitamin $\mathrm{C}$ and the role of oxygen in ascorbic acid degradation, and conditions encountered in the laboratory (such as small volumes and large surfaces for exchange with ambient air) may not be totally representative of industrial conditions.

Losses in degassed and nondegassed tamarillo nectars kept for $10 \mathrm{~min}$ at $95^{\circ} \mathrm{C}$ were of $4 \%$ and $100 \%$, respectively, for ascorbic acid but $75 \%$ and $80 \%$, respectively, for dehydroascorbic acid [173]. Similar losses of vitamin C (ca. 15\%) in orange juices are reported for various ohmic conditions and conventional pasteurization $\left(90^{\circ} \mathrm{C}, 50 \mathrm{~s}\right)$ [134]. Mild pasteurization $\left(75^{\circ} \mathrm{C}, 10 \mathrm{~min}\right)$ of a highly acidic ( $\mathrm{pH}$ 3.2) apple puree (vitamin $\mathrm{C}$ coming from added acerola and lemon juice) did not decrease total vitamin $\mathrm{C}$ but decreased ascorbic acid by $38.5 \%$ [174]. For apricots in syrup, a loss of $18 \%$ of ascorbic acid was registered during ohmic heating (and a further loss of $28 \%$ in the first weeks of storage) [175]. For ascorbic acid, $E_{a}$ of $36 \mathrm{~kJ} \mathrm{~mol}^{-1}\left(z=64^{\circ} \mathrm{C}\right)$ was found in mixed orange and clementine juice [176], $E_{a}=38.6 \mathrm{~kJ} \mathrm{~mol}^{-1}$ (initial steps only) in orange juice under aerobic condition [177], and $E_{a}=47.5 \mathrm{~kJ} \mathrm{~mol}^{-1}\left(z=53^{\circ} \mathrm{C}\right.$, with $\left.D_{90^{\circ} \mathrm{C}}=175 \mathrm{~min}\right)$ in rose hip pulp [178].

The other factor that may contribute to vitamin C loss is its solubility, so that it may leach during blanching and diffuse to the covering liquid during storage. Vitamin $\mathrm{C}$ concentrations are often higher in the outer parts of the fruit, so that peeling or sieving also contributes to its loss $[179,180]$.

\subsubsection{Carotenoids}

Carotenoids are tetraterpenoid organic pigments characterized by their lipophilic character. They can be divided into xanthophylls (lutein) that contain oxygen, and carotenes (notably $\beta$-carotene and lycopene), which are purely hydrocarbons and thus even more lipophilic. They can also be categorized according to their nutritional status in provitamin A ( $\beta$-carotene, $\alpha$-carotene, $\gamma$-carotene, and $\beta$-cryptoxanthin) and nonprovitamin A carotenoids. Many studies report the impact of heat treatments on carotenoids, with contradictory results, but globally these compounds appear to be relatively stable $[181,182]$. There also appears to be differences in stability, with xanthophylls being less stable than the carotenes [176,183-185].

In raw natural foods, all-trans isomers of carotenoids are dominant but mono or poly-cis isomers are formed upon heating. Carotenoids are susceptible to oxidation, with first formation of epoxides followed by chain cleavage leading to apo-carotenals. Upon moderate heat treatment of tissues, there is commonly an increase in apparent carotenoid content, which is usually ascribed to easier extractability [186-189]. Prolonged heating and presence of oil seem to favor isomerization, while oxidation is favored by heat, low water activities, and of course presence of oxygen $[190,191]$. Carotenoid degradation follows first-order kinetics and is strongly correlated to color degradation $[173,176,192,193]$.

Pasteurization can lead to a loss of carotenoids in orange juice, with violaxanthine and lutein being the most thermolabile; concentration of the juices further affects lutein concentrations. The provitamin A carotenoids are not significantly degraded [184]. Using microwave heating [185], $z$ values between $10.9^{\circ} \mathrm{C}\left(\beta\right.$-carotene, with $\left.D_{70^{\circ} \mathrm{C}}=24.6 \mathrm{~min}\right)$ and $16.7^{\circ} \mathrm{C}$ (antheraxanthin, with $D_{70^{\circ} \mathrm{C}}=8.5 \mathrm{~min}$ ) are reported for carotenoids in orange juice. Activation energies of 110 and $156 \mathrm{~kJ} \mathrm{~mol}^{-1}$ ( $z$ of $22.5^{\circ} \mathrm{C}$ and $15.9^{\circ} \mathrm{C}$ ) for $\beta$-carotene and $\beta$-cryptoxanthin were found in mixed orange and clementine juice [176]. Cold storage of frozen fruits, fruit purées, or concentrated fruit juices can lead to loss in carotenoids [181,194], especially in plastic containers, probably because plastic containers allow some oxygen permeability. Degradation of carotenoids is not affected by the level of dissolved oxygen in tamarillo juice [173]. 
The most remarkable effect of heat treatment on carotenoids in intact tissues is a marked increase of their bioavailability, noticed first in vivo [195-197] and studied in detail using in vitro models [198]. This increase in bioaccessibility/bioavailability of carotenoids appears linked to cell wall degradation, enhancing cell rupture [199-203]. High-pressure processing in contrast decreases carotenoids bioaccessibility, which can be related to pectin methylesterase activity and calciummediated cross-linking of the polysaccharides in the cell walls [204,205].

Carotenoids are not water soluble. In juice processing, carotenoids are linked to the pulp, and they can be present in quite high concentrations in pulpy juices such as juices made from apricot, mango or guava, which are actually comminuted rather than pressed. Furthermore, carotenoids are often concentrated in the outer tissues of plants: peeling and sieving also contribute to a decrease of their amounts in the processed products [180].

\subsubsection{Dietary Fiber}

Dietary fiber in fruits corresponds to polysaccharides (and traces of lignin) constituting their cell walls. Thermal treatments have limited impact on the total dietary fiber contents. They generally lead to a modification of the soluble/insoluble fiber balance by an increase in soluble fibers [51,206], due to pectin degradation [79]. This also leads to increased cell wall swelling.

Pressing eliminates insoluble dietary fibers from the juice, as they are retained in the pomace; the residual fibers are further eliminated upon clarification. Only minor amounts are present as cloud in cloudy juices, typically $<0.5 \mathrm{~g} \mathrm{~L}^{-1}$. Peeling and sieving also retain the harder tissues, which are also the ones that are rich in dietary fibers, for example, in purées, smoothies, or pulpy juices [51]. Though the dietary fiber contents are higher than in juices, there is still a significant loss compared to whole fruits (though not necessarily when compared to fruit flesh [207]).

\subsection{CONCLUSIONS}

Processed fruits generally undergo mild heat treatments as their low $\mathrm{pH}$ is a good protection against pathogenic bacteria. A specific characteristic for fruit juices is that they may have spent long durations at only slightly elevated temperatures $\left(40^{\circ} \mathrm{C}-50^{\circ} \mathrm{C}\right)$ for ease of processing (enzymation before or after pressing, concentration, filtration, etc.), which may result in quality modifications in particular concerning aromas. The current trends in industrial heat processing of fruits are to minimize the process intensity, both for better preservation of organoleptic and nutritional properties and for more durable processes. Fruit juices in particular are an area of active research and product development in nonthermal stabilization technologies. There has been however in the recent past increased reports of fruit juice contamination with pathogenic microorganisms such as E. coli O157:H7. These are linked to increased demand for fresh, unpasteurized products, and highlight the necessity for vigilance from manufacturers and public authorities.

Fruits used for processing have undergone a remarkable diversification in the last few years, including more and more exotic fruits. Some of these fruits have higher $\mathrm{pH}$ than the more classical citrus and pome fruits, and therefore, more attention should be paid to microbial inactivation. Among the popular fruits, mango, lychee, and sometimes pear may only require some mild acidification (typically citric acid) as their pHs are of about 4.5-5. Guava, cantaloupe, and watermelon or banana with $\mathrm{pHs}>5$ need more stringent thermal treatments.

\section{NOMENCLATURE}

$\begin{array}{ll}a^{*} & \text { Measure of greenness-redness }(-) \\ b^{*} & \text { Measure of blueness-yellowness }(-) \\ b(\vartheta) & \text { Parameter of the Equation 16.5 derived from a Weibull distribution (min) } \\ C(t) & \text { Quality attribute level at a time } t \\ C_{0} & \text { Initial quality attribute level }\end{array}$


$C_{\infty} \quad$ Quality attribute level at equilibrium

$C^{*} \quad$ Chroma index (一)

$D_{\text {ref }} \quad$ Decimal reduction time at reference temperature (min)

$D(\vartheta) \quad$ Decimal reduction time at temperature $\vartheta(\mathrm{min})$

$E_{a} \quad$ Activation energy $\left(\mathrm{kJ} \mathrm{mol}^{-1}\right)$

$f(t) \quad$ Fractional conversion at a time $t(-)$

$F \quad$ Process thermal lethality (min)

$F_{0} \quad$ Process thermal lethality at $121.1^{\circ} \mathrm{C}(\mathrm{min})$

$k(\vartheta) \quad$ Inactivation "rate constant" at temperature $\vartheta\left(\mathrm{min}^{-1}\right)$

$k_{1}, k_{2} \quad$ Coefficients of the biphasic model $\left(\mathrm{min}^{-1}\right)$

$K \quad$ Parameter of the Herschel-Bulkley equation $\left(\mathrm{Pa} \mathrm{s}^{n}\right)$

$K 1, K 2, K 3 \quad$ Reaction constants of ascorbic acid degradation in aerobic conditions

$L^{*} \quad$ Lightness (-)

$n \quad$ Parameter of the Herschel-Bulkley equation (-)

$N_{0} \quad$ Initial number of spores or microorganisms

$N(t) \quad$ Number of spores or microorganisms at time $t$

$q \quad$ Coefficient of the biphasic model (-)

$R \quad$ Universal gas constant $\left(8.314 \mathrm{~J} \mathrm{~mol}^{-1}{ }^{\circ} \mathrm{C}^{-1}\right)$

$t \quad$ Time (min for reaction kinetics)

$T \quad$ Absolute temperature (K)

TCD* Total color difference (-)

Z Temperature difference required for 10 -fold change in $D$ value $\left({ }^{\circ} \mathrm{C}\right)$

\section{Greek}

$\beta$

$\vartheta_{\text {ref }}$

$\dot{\gamma}$

$\tau$

$\tau_{0}$

Power parameter of the Equation 16.5 derived from a Weibull distribution (-)

Reference temperature $\left({ }^{\circ} \mathrm{C}\right)$

Shear rate $\left(\mathrm{s}^{-1}\right)$

Stress $(\mathrm{Pa})$

Yield stress $(\mathrm{Pa})$

\section{REFERENCES}

1. E Rendueles et al. Microbiological food safety assessment of high hydrostatic pressure processing: A review. LWT_Food Science and Technology 44(5):1251-1260, 2011.

2. D Bermudez-Aguirre and GV Barbosa-Canovas. An update on high hydrostatic pressure, from the laboratory to industrial applications. Food Engineering Reviews 3(1):44-61, 2011.

3. G Demazeau and N Rivalain. The development of high hydrostatic pressure processes as an alternative to other pathogen reduction methods. Journal of Applied Microbiology 110(6):1359-1369, 2011.

4. D Knorr et al. Emerging technologies in food processing. Annual Review of Food Science and Technology 2:203-235, 2011.

5. MB Fox et al. Inactivation of L-plantarum in a PEF microreactor-The effect of pulse width and temperature on the inactivation. Innovative Food Science \& Emerging Technologies 9(1):101-108, 2008.

6. CE Missang et al. Texture variation in apricot: Intra-fruit heterogeneity, impact of thinning and relation with the texture after cooking. Food Research International 44(1):46-53, 2011.

7. E Bourles et al. Impact of vacuum cooking process on the texture degradation of selected apple cultivars. Journal of Food Science 74(9):E512-E518, 2009.

8. SF Aguillar-Rosas et al. Thermal and pulsed electric fields pasteurization of apple juice: Effects on physicochemical properties and flavour compounds. Journal of Food Engineering 83(1):41-46, 2007.

9. PR Perez-Cacho and R Rouseff. Processing and storage effects on orange juice aroma: A review. Journal of Agricultural and Food Chemistry 56(21):9785-9796, 2008.

10. MP Nikfardjam and D Maier. Development of a headspace trap HRGC/MS method for the assessment of the relevance of certain aroma compounds on the sensorial characteristics of commercial apple juice. Food Chemistry 126(4):1926-1933, 2011. 
11. A Kalia and RP Gupra. Fruit microbiology. In: YH Hui, ed. Handbook of Fruits and Fruits Processing. Blachwell Publishing, 2006, pp. 3-28.

The Nguyen and F Carlin. The microbiology of minimally processed fresh fruits and vegetables. Critical Reviews in Food Science and Nutrition 34:371-401, 1994.

13. F Carlin et al. Research on factors allowing a risk assessment of spore-forming pathogenic bacteria in cooked chilled foods containing vegetables: A FAIR collaborative project. International Journal of Food Microbiology 60(2/3):117-135, 2000.

14. MAJS van Boekel. Kinetics of inactivation of microorganisms. In: MAJS van Boekel, ed. Kinetic Modeling in Reactions in Foods. Boca Raton, FL:CRC Press, Taylor \& Francis Group, 2009, pp. 13-1, 13-44.

15. MAJS van Boekel. On the use of the Weibull model to describe thermal inactivation of microbial vegetative cells. International Journal of Food Microbiology 74(1-2):139-159, 2002.

16. M Corrandini and M Peleg. The non linear kinetics of microbial inactivation and growths in foods. In: S Brul, S van Gerwen, and M Zwietering, eds. Modelling Microorganisms in Food. Cambridge, U.K.: Woodhead Publishing Limited, 2007, pp. 129-160.

17. P Mafart et al. On calculating sterility in thermal preservation methods: Application of the Weibull frequency distribution model. International Journal of Food Microbiology 72(1-2):107-113, 2002.

18. O Couvert et al. Survival curves of heated bacterial spores: Effect of environmental factors on Weibull parameters. International Journal of Food Microbiology 101(1):73-81, 2005.

19. M Peleg. A model of survival curves having an "activation shoulder." Journal of Food Science 67(7):24382443, 2002.

20. AH Geeraerd, CH Herremans, and JF Van Impe. Structural model requirements to describe microbial inactivation during a mild heat treatment. International Journal of Food Microbiology 59(3):185-209, 2000 .

21. AH Geeraerd, VP Valdramidis, and JF Van Impe. GInaFiT, a freeware tool to assess non-log-linear microbial survivor curves. International Journal of Food Microbiology 102(1):95-105, 2005.

22. R Xiong et al. A mathematical model for bacterial inactivation. International Journal of Food Microbiology 46(1):45-55, 1999.

23. G Stone, B Chapman, and D Lovell. Development of a log-quadratic model to describe microbial inactivation, illustrated by thermal inactivation of Clostridium botulinum. Applied and Environmental Microbiology 75(22):6998-7005, 2009.

24. L Dong-Un, V Heinz, and D Knorr. Biphasic inactivation kinetics of Escherichia coli in liquid whole egg by high hydrostatic pressure treatments. Biotechnology Progress 17(6):1020-1025, 2001.

25. P Mafart et al. Quantification of spore resistance for assessment and optimization of heating processes: A never-ending story. Food Microbiology 27(5):568-572, 2010.

26. P Pittia et al. Safe cooking optimisation by F-value computation in a semi-automatic oven. Food Control 19(7):688-697, 2008.

27. CE Steyn, M Cameron, and RC Witthuhn. Occurrence of Alicyclobacillus in the fruit processing environment-A review. International Journal of Food Microbiology 147(1):1-11, 2011.

28. WH Groenewald, PA Gouws, and RC Witthuhn. Isolation, identification and typification of Alicyclobacillus acidoterrestris and Alicyclobacillus acidocaldarius strains from orchard soil and the fruit processing environment in South Africa. Food Microbiology 26(1):71-76, 2009.

29. Y Smit et al. Alicyclobacillus spoilage and isolation-A review. Food Microbiology 28(3):331-349, 2011.

30. FVM Silva and P Gibbs. Alicyclobacillus acidoterrestris spores in fruit products and design of pasteurization processes. Trends in Food Science \& Technology 12(2):68-74, 2001.

31. MC Maldonado, C Belfiore, and AR Navarro. Temperature, soluble solids and $\mathrm{pH}$ effect on Alicyclobacillus acidoterrestris viability in lemon juice concentrate. Journal of Industrial Microbiology \& Biotechnology 35(2):141-144, 2008.

32. FVM Silva and P Gibbs. Target selection in designing pasteurization processes for shelf-stable high-acid fruit products. Critical Reviews in Food Science and Nutrition 44(5):353-360, 2004.

33. BdC Martins Salomao, P Rodriguez Massaguer, and GM Falcao Aragao. Isolation and selection of heat resistant molds in the production process of apple nectar. Ciencia e Tecnologia de Alimentos 28(1):116$121,2008$.

34. M Zimmermann et al. Modeling the influence of water activity and ascospore age on the growth of Neosartorya fischeri in pineapple juice. LWT_Food Science and Technology 44(1):239-243, 2011.

35. AdS Sant'Ana, A Rosenthal, and PRd Massaguer. The fate of patulin in apple juice processing: A review. Food Research International 41(5):441-453, 2008. 
36. AA Lima Tribst, Ad Souza Sant'Ana, and PRd Massaguer. Review: Microbiological quality and safety of fruit juices-Past, present and future perspectives. Critical Reviews in Microbiology 35(4):310-339, 2009.

37. TR Stoneham, DB Lund, and CH Tong. The use of fractional conversion technique to investigate the effects of testing parameters on texture degradation kinetics. Journal of Food Science 65(6):968-973, 2000.

38. R Villota and JG Hawkes. Reaction kinetics in food systems. In: L Heldman, ed. Handbook of Food Engineering. Boca Raton, FL: CRC Press, 2007, pp. 125-286.

39. Y Kim, JK Brecht, and ST Talcott. Antioxidant phytochemical and fruit quality changes in mango (Mangifera indica L.) following hot water immersion and controlled atmosphere storage. Food Chemistry 105(4):1327-1334, 2007.

40. C Noe-Aguilar et al. Blanching at low temperatures: A thermal bioprocess applied to fruits and vegetables to improve textural quality. Food Science and Biotechnology 13(1):104-108, 2004.

41. EB Solomon et al. Thermal inactivation of salmonella on cantaloupes using hot water. Journal of Food Science 71(2):M25-M30, 2006.

42. JB Adams. Review: Enzyme inactivation during heat processing of food-stuffs. International Journal of Food Science \& Technology 26(1):1-20, 1991.

43. LN Gerschenson, AM Rojas, and AG Marangoni. Effects of processing on kiwi fruit dynamic rheological behaviour and tissue structure. Food Research International 34(1):1-6, 2001.

44. Z Yi and P Zhongli. Processing and quality characteristics of apple slices under simultaneous infrared dry-blanching and dehydration with continuous heating. Journal of Food Engineering 90(4):441-452, 2009.

45. Z Yi et al. Processing and quality characteristics of apple slices processed under simultaneous infrared dry-blanching and dehydration with intermittent heating. Journal of Food Engineering 97(1):8-16, 2010.

46. H Yildiz, H Bozkurt, and F Icier. Ohmic and conventional heating of pomegranate juice: Effects on rheology, color, and total phenolics. Food Science and Technology International 15(5):503-512, 2009.

47. S Mukherjee and PK Chattopadhyay. Whirling bed blanching of potato cubes and its effects on product quality. Journal of Food Engineering 78(1):52-60, 2007.

48. EMC Alexandre et al. Influence of aqueous ozone, blanching and combined treatments on microbial load of red bell peppers, strawberries and watercress. Journal of Food Engineering 105(2):277-282, 2011.

49. MV Selma et al. Effect of gaseous ozone and hot water on microbial and sensory quality of cantaloupe and potential transference of Escherichia coli O157:H7 during cutting. Food Microbiology 25(1):162$168,2008$.

50. RP Singh. Heating and cooling processes for foods. In: DR Heldman, DB Lund, eds. Handbook of Food Engineering. Boca Raton, FL: CRC Press, Taylor \& Francis Group, 2007, pp. 397-426.

51. M Colin-Henrion et al. Instrumental and sensory characterisation of industrially processed applesauces. Journal of the Science of Food and Agriculture 89(9) 1508-1518, 2009.

52. A Teixeira. Thermal processing of canned foods. In: DR Heldman and DB Lund, eds. Handbook of Food Engineering. Boca Raton, FL: CRC Press, 2007, pp. 745-797.

53. M Siddiq. Apricots. In: HY Hui, ed. Handbook of Fruits and Fruits Processing. Ames, IA: Blackwell Publishing, 2006, pp. 279-291.

54. M Siddiq. Peach and nectarine. In: HY Hui, ed. Handbook of Fruits and Fruits Processing. Ames, IA: Blackwell Publishing, 2006, pp. 519-531.

55. M Siddiq. Plums and prunes. In: HY Hui, ed. Handbook of Fruits and Fruits Processing. Ames, IA: Blackwell Publishing, 2006, pp. 553-564.

56. JV Carbonell et al. Chilled orange juices stabilized by centrifugation and differential heat treatments applied to low pulp and pulpy fractions. Innovative Food Science and Emerging Technologies 12(3):315319, 2011.

57. C Chen, K Abdelrahim, and I Beckerich. Sensitivity analysis of continuous ohmic heating process for multiphase foods. Journal of Food Engineering 98(2):257-265, 2010.

58. F Marra, Z Lu, and JG Lyng. Radio frequency treatment of foods: Review of recent advances. Journal of Food Engineering 91(4):497-508, 2009.

59. Nd Belie et al. Use of physico-chemical methods for assessment of sensory changes in carrot texture and sweetness during cooking. Journal of Texture Studies 33(5):367-388, 2002.

60. K Roininen et al. Perceived eating difficulties and preferences for various textures of raw and cooked carrots in young and elderly subjects. Journal of Sensory Studies 18(6):437-451, 2003.

61. M Bourne, ed. Food Texture and Viscosity: Concepts and Measurements, 2nd edn. London, U.K.: Academic Press, 2002. 
62. E Madieta, R Symoneaux, and E Mehinagic. Textural properties of fruit affected by experimental conditions in TPA tests: An RSM approach. International Journal of Food Science \& Technology 46(5):10441052, 2011.

63. MB Sousa et al. Effect of processing on the texture and sensory attributes of raspberry (cv. Heritage) and blackberry (cv. Thornfree). Journal of Food Engineering 78(1):9-21, 2007.

64. FR Harker et al. Instrumental measurement of apple texture: A comparison of the single-edge notched bend test and the penetrometer. Postharvest Biology and Technology 39(2):185-192, 2006.

65. G Roudaut et al. Crispness: A critical review on sensory and material science approaches. Trends in Food Science \& Technology 13(6-7):217-227, 2002.

66. Y Yoshioka et al. Quantifying cucumber fruit crispness by mechanical measurement. Breeding Science 59(2):139-147, 2009.

67. F Costa et al. Assessment of apple (Malus * domestica Borkh.) fruit texture by a combined acousticmechanical profiling strategy. Postharvest Biology and Technology 61(1):21-28, 2011.

68. C Zheng, D-W Sun, and L Zheng. Recent developments and applications of image features for food quality evaluation and inspection-A review. Trends in Food Science \& Technology 17(12):642-655, 2006.

69. R Yoruk et al. Machine vision analysis of antibrowning potency for oxalic acid: A comparative investigation on banana and apple. Journal of Food Science 69(6):E281-E289, 2004.

70. R Quevedo et al. Determination of senescent spotting in banana (Musa cavendish) using fractal texture Fourier image. Journal of Food Engineering 84(4):509-515, 2008.

71. R Quevedo et al. Description of the kinetic enzymatic browning in banana (Musa cavendish) slices using non-uniform color information from digital images. Food Research International 42(9):1309-1314, 2009.

72. L Fernández, C Castillero, and JM Aguilera. An application of image analysis to dehydration of apple discs. Journal of Food Engineering 67(1-2):185-193, 2005.

73. J Suutarinen et al. The effects of calcium chloride and sucrose prefreezing treatments on the structure of strawberry tissues. Lebensmittel-Wissenschaft und-Technologie 33(2):89-102, 2000.

74. Sv Buggenhout et al. Minimizing texture loss of frozen strawberries: Effect of infusion with pectinmethylesterase and calcium combined with different freezing conditions and effect of subsequent storage/ thawing conditions. European Food Research and Technology 223(3):395-404, 2006.

75. HK Mebatsion et al. Modelling fruit (micro)structures, why and how? Trends in Food Science \& Technology 19(2):59-66, 2008.

76. ML Oey et al. Effect of turgor on micromechanical and structural properties of apple tissue: A quantitative analysis. Postharvest Biology and Technology 44(3):240-247, 2007.

77. A Zdunek et al. New contact acoustic emission detector for texture evaluation of apples. Journal of Food Engineering 99(1):83-91, 2010.

78. A Zdunek et al. Evaluation of apple texture with contact acoustic emission detector: A study on performance of calibration models. Journal of Food Engineering 106(1):80-87, 2011

79. AGJ Voragen et al. Pectins. In: AM Stephen and I Dea, eds. Food Polysaccharide Darcel Dekk 295 , pp. 287-339.

80. GE Anthon and DM Barrett. Characterization of the temperature activation of pectin methylesterase in green beans and tomatoes. Journal of Agricultural and Food Chemistry 54(1):204-211, 2006.

81. SM Krall and RF McFeeters. Pectin hydrolysis: Effect of temperature, degree of methylation, $\mathrm{pH}$, and calcium on hydrolysis rates. Journal of Agricultural and Food Chemistry 46(4):1311-1315, 1998.

82. T Sajjaanantakul, JP Van Buren, and DL Downing. Effect of cations on heat degradation of chelatorsoluble carrot pectin. Carbohydrate Polymers 20(3):207-214, 1993.

83. T Duvetter et al. Pectins in processed fruit and vegetables: Part I-Stability and catalytic activity of pectinases. Comprehensive Reviews in Food Science and Food Safety 8(2):75-85, 2009.

84. JM Denes, A Baron, and JF Drilleau. Purification, properties and heat inactivation of pectin methylesterase from apple (cv Golden Delicious). Journal of the Science of Food and Agriculture 80(10):1503-1509, 2000 .

85. AR Hirsch et al. Impact of minimal heat-processing on pectin methylesterase and peroxidase activity in freshly squeezed Citrus juices. European Food Research and Technology 232(1):71-81, 2011.

86. T Sajjaanantakul, JP Van Buren, and DL Downing. Effect of methyl ester content on heat degradation of chelator-soluble carrot pectin. Journal of Food Science 54(5):1272-1277, 1989.

87. ACK Sato, EJ Sanjinez-Argandona, and RL Cunha. The effect of addition of calcium and processing temperature on the quality of guava in syrup. International Journal of Food Science and Technology 41(4):417-424, 2006. 
88. CN Aguilar et al. Blanching at low temperatures: A thermal bioprocess applied to fruits and vegetables to improve textural quality. Food Science and Biotechnology 13(1):104-108, 2004.

AQ6 89. J Ahmed and US Shivhare. Thermal processing of vegetables. In: DW Sun, ed. Thermal Food Processing. Boca Raton, FL: CPC Press, Taylor \& Francis Group, 200

90. P Varoquaux, M Souty, and F Varoquaux. Water blanching on whole apricots. Sciences Des Aliments 6(4):591-600, 1986.

91. IAG Weinert, J Solms, and F Escher. Quality of canned plums with varying degrees of ripeness. II. Texture measurements and sensory evaluation of texture and colour. Lebensmittel-Wissenschaft und -Technologie 23(2):117-121, 1990.

92. B Qi, KG Moore, and J Orchard. Effect of cooking on banana and plantain texture. Journal of Agricultural and Food Chemistry 48(9):4221-4226, 2000.

93. CG Mallidis and C Katsaboxakis. Effect of thermal processing on the texture of canned apricots. International Journal of Food Science \& Technology 37(5):569-572, 2002.

94. NI Lebovka, I Praporscic, and E Vorobiev. Effect of moderate thermal and pulsed electric field treatments on textural properties of carrots, potatoes and apples. Innovative Food Science and Emerging Technologies 5(1):9-16, 2004.

95. AC Kawazoe Sato, R Lopes da Cunha, and EJ Sanjinez-Argandona. Evaluation of colour, texture and mass transfer during guava in syrup processing. Brazilian Journal of Food Technology 8(2):149-156, 2005.

96. S Beirao-da-Costa et al. Effects of maturity stage and mild heat treatments on quality of minimally processed kiwifruit. Journal of Food Engineering 76(4):616-625, 2006.

97. A Karthiayani and CT Devadas. Textural properties of canned banana. Journal of Food Science and Technology 44(4):440-442, 2007.

98. A Koukounaras, G Diamantidis, and E Sfakiotakis. The effect of heat treatment on quality retention of fresh-cut peach. Postharvest Biology and Technology 48(1):30-36, 2008.

99. AH Rather et al. Effect of fruit ripeness and calcium chloride on the quality of canned Bartlett pears. Advances in Food Sciences 31(2):109-113, 2009.

100. O Gibert et al. A kinetic approach to textural changes of different banana genotypes (Musa sp.) cooked in boiling water in relation to starch gelatinization. Journal of Food Engineering 98(4):471-479, 2010.

101. C Ella Missang et al. Texture variation in apricot: Intra-fruit heterogeneity, impact of thinning and relation with the texture after cooking. Food Research International 44(1):46-53, 2011.

102. MV Shynkaryk et al. Ohmic heating of peaches in the wide range of frequencies ( $50 \mathrm{hz}$ to $1 \mathrm{mhz})$. Journal of Food Science 75(7):E493-E500, 2010.

103. E Vorobiev and N Lebovka. Enhanced extraction from solid foods and biosuspensions by pulsed electrical energy. Food Engineering Reviews 2(2):95-108, 2010.

104. C Nunes et al. Effect of candying on microstructure and texture of plums (Prunus domestica L.). LWT-Food Science and Technology 41(10):1776-1783, 2008.

105. JM Barat et al. Pineapple candying at mild temperature by applying vacuum impregnation. Journal of Food Science 67(8):3046-3052, 2002.

106. J Giner et al. Rheology of clarified cherry juices. Journal of Food Engineering 30(1/2):147-154, 1996.

107. CA Zuritz et al. Density, viscosity and coefficient of thermal expansion of clear grape juice at different soluble solid concentrations and temperatures. Journal of Food Engineering 71(2):143-149, 2005.

108. A Altan and M Maskan. Rheological behavior of pomegranate (Punica granatum L.) juice and concentrate. Journal of Texture Studies 36(1):68-77, 2005.

109. R Ibarz et al. Flow behavior of clarified orange juice at low temperatures. Journal of Texture Studies 40(4):445-456, 2009.

110. NL Chin et al. Modelling of rheological behaviour of pummelo juice concentrates using master-curve. Journal of Food Engineering 93(2):134-140, 2009.

111. V Falguera and A Ibarz. A new model to describe flow behaviour of concentrated orange juice. Food Biophysics 5(2):114-119, 2010.

112. D Gabriele, M Migliori, and Bd Cindio. Innovation in fig syrup production process: A rheological approach. International Journal of Food Science \& Technology 45(9):1947-1955, 2010.

113. D Bergamaschi Guedes, A Mota Ramos, and MD Martins Silva Diniz. Effect of temperature and concentration on the physical properties of watermelon pulp. Brazilian Journal of Food Technology 13(4):279_ 285,2010

114. AM Sharoba and MF Ramadan. Rheological behavior and physicochemical characteristics of goldenberry (Physalis peruviana) juice as affected by enzymatic treatment. Journal of Food Processing and Preservation 35(2):201-219, 2011. 
115. N Grigelmo-Miguel, A Ibarz-Ribas, and O Martin-Belloso. Flow properties of orange dietary fiber suspensions. Journal of Texture Studies 30(3):245-257, 1999.

116. N Grigelmo-Miguel, A Ibarz-Ribas, and O Martin-Belloso. Rheology of peach dietary fibre suspensions. Journal of Food Engineering 39(1):91-99, 1999.

117. MK Krokida, ZB Maroulis, and GD Saravacos. Rheological properties of fluid fruit and vegetable puree products: Compilation of literature data. International Journal of Food Properties 4(2):179-200, 2001.

118. R Fügel, R Carle, and A Schieber. Quality and authenticity control of fruit purées, fruit preparations and jams-A review. Trends in Food Science \& Technology 16(10):433-441, 2005.

119. R Maceiras, E Álvarez, and MA Cancela. Rheological properties of fruit purees: Effect of cooking. Journal of Food Engineering 80(3):763-769, 2007.

120. JF Maingonnat, L Muller, and JC Leuliet. Modelling the build-up of a thixotropic fluid under viscosimetric and mixing conditions. Journal of Food Engineering 71(3):265-272, 2005.

121. JE Lozano and A Ibarz. Thixotrophic behaviour of concentrated fruit pulps. Lebensmittel-Wissenschaft und-Technologie 27(1):16-18, 1994.

122. V Hegedusic, T Lovric, and A Parmac. Influence of phase transition (freezing and thawing) on thermophysical and rheological properties of apple puree-like products. Acta Alimentaria 22(4):337-349, 1993.

123. AM Ramos and A Ibarz. Thixotropy of orange concentrate and quince puree. Journal of Texture Studies 29(3):313-324, 1998.

124. S Bhattacharya. Yield stress and time-dependent rheological properties of mango pulp. Journal of Food Science 64(6):1029-1033, 1999.

125. V Speiciene et al. Rheological properties of currant purees and jams: Effect of composition and method of proceeding. Journal of Food, Agriculture \& Environment 6(3-4):162-166, 2008.

126. B Santanu, US Shivhare, and GSV Raghavan. Time dependent rheological characteristics of pineapple jam. International Journal of Food Engineering 3(3), 2007.

127. RR Milczarek and KL McCarthy. Relationship between the Bostwick measurement and fluid properties. Journal of Texture Studies 37(6):640-654, 2006.

128. KL McCarthy, RF Sacher, and TC Garvey. Relationship between rheological behavior and Bostwick measurement during manufacture of ketchup. Journal of Texture Studies 39(5):480-495, 2008.

129. S Croak and M Corredig. The role of pectin in orange juice stabilization: Effect of pectin methylesterase and pectinase activity on the size of cloud particles. Food Hydrocolloids 20(7):961-965, 2006.

130. H Lee et al. De-esterification pattern of Valencia orange pectinmethylesterases and characterization of modified pectins. Journal of the Science of Food and Agriculture 88(12):2102-2110, 2008.

131. J Carbonell et al. Pectin methylesterase activity in juices from mandarins, oranges and hybrids. European Food Research and Technology 222(1):83-87, 2006.

132. LSFCA Collet et al. A kinetic study on pectinesterase inactivation during continuous pasteurization of orange juice. Journal of Food Engineering 69(1):125-129, 2005.

133. B Ingallinera et al. Effects of thermal treatments on pectinesterase activity determined in blood oranges juices. Enzyme and Microbial Technology 36(2-3):258-263, 2005.

134. S Leizerson and E Shimoni. Effect of ultrahigh-temperature continuous ohmic heating treatment on fresh orange juice. Journal of Agricultural and Food Chemistry 53(9):3519-3524, 2005.

135. F Sampedro, D Rodrigo, and M Hendrickx. Inactivation kinetics of pectin methyl esterase under combined thermal-high pressure treatment in an orange juice-milk beverage. Journal of Food Engineering 86(1):133-139, 2008.

136. E Sentandreu et al. Effects of heat treatment conditions on fresh taste and on pectinmethylesterase activity of chilled mandarin and orange juices. Food Science and Technology International 11(3):217-222, 2005.

137. TB Tribess and CC Tadini. Inactivation kinetics of pectin methyl-esterase in orange juice as a function of $\mathrm{pH}$ and temperature/time process conditions. Journal of the Science of Food and Agriculture 86(9):13281335, 2006.

138. L Wicker and F Temelli. Heat inactivation of pectinesterase in orange juice pulp. Journal of Food Science 53(1):162-164, 1988.

139. S Tajchakavit and HS Ramaswamy. Thermal vs. microwave inactivation kinetics of pectin methylesterase in orange juice under batch mode heating conditions. Lebensmittel-Wissenschaft und-Technologie 30(1):85-93, 1997.

140. A Espachs-Barroso et al. Inactivation of plant pectin methylesterase by thermal or high intensity pulsed electric field treatments. Innovative Food Science and Emerging Technologies 7(1-2):40-48, 2006. 
141. de SA Assis, ABG Martins, and OMM de Faria Oliveira. Purification and characterization of pectin methylesterase from acerola (Malpighia glabra L.). Journal of the Science of Food and Agriculture 87(10):1845-1849, 2007.

142. CS Nunes et al. Thermal and high-pressure stability of purified pectin methylesterase from plums (Prunus Domestica). Journal of Food Biochemistry 30(2):138-154, 2006.

143. Y Guiavarc'h et al. Purification, characterization, thermal and high-pressure inactivation of a pectin methylesterase from white grapefruit (Citrus paradisi). Innovative Food Science \& Emerging Technologies 6(4):363-371, 2005.

144. FJ Francis. Colorimetric properties of foods. In: MA Rao, SSH Rizvi, and AK Datta, eds. Engineering Properties of Foods. Boca Raton, FL: CRC Press, Taylor \& Francis Group, 2005, pp. 703-732.

145. IMLB Avila and CLM Silva. Modelling kinetics of thermal degradation of colour in peach puree. Journal of Food Engineering 39(2):161-166, 1999.

146. FM Silva and CLM Silva. Colour changes in thermally processed cupuacu (Theobroma grandiflorum) puree: Critical times and kinetics modelling. International Journal of Food Science \& Technology 34(1):87-94, 1999.

147. S Garza et al. Non-enzymatic browning in peach puree during heating. Food Research International 32(5):335-343, 1999.

148. C Benjar and $\mathrm{N}$ Athapol. Color degradation kinetics of pineapple puree during thermal processing. LWT_Food Science and Technology 40(2):300-306, 2007.

149. A Patras et al. Impact of high pressure processing on total antioxidant activity, phenolic, ascorbic acid, anthocyanin content and colour of strawberry and blackberry purees. Innovative Food Science and Emerging Technologies 10(3):308-313, 2009.

150. J Garcia-Parra et al. Effect of thermal and high-pressure processing on the nutritional value and quality attributes of a nectarine puree with industrial origin during the refrigerated storage. Journal of Food Science 76(4):C618-C625, 2011.

151. M Rattanathanalerk, N Chiewchan, and W Srichumpoung. Effect of thermal processing on the quality loss of pineapple juice. Journal of Food Engineering 66(2):259-265, 2005.

152. MR Mosshammer et al. Impact of thermal treatment and storage on color of yellow-orange cactus pear (Opuntia ficus-indica L. Mill. cv. "Gialla”) juices. Journal of Food Science 71(7):C400-C406, 2006.

153. KM Herbach et al. Effects of processing and storage on juice colour and betacyanin stability of purple pitaya (Hylocereus polyrhizus) juice. European Food Research and Technology 224(5):649-658, 2007.

154. D Rodrigo, Av Loey, and M Hendrickx. Combined thermal and high pressure colour degradation of tomato puree and strawberry juice. Journal of Food Engineering 79(2):553-560, 2007.

155. LF Damasceno et al. Non-enzymatic browning in clarified cashew apple juice during thermal treatment: Kinetics and process control. Food Chemistry 106(1):172-179, 2008.

156. L Queiroz Zepka et al. Thermal degradation kinetics of carotenoids in a cashew apple juice model and its impact on the system color. Journal of Agricultural and Food Chemistry 57(17):7841-7845, 2009.

157. E Sadilova et al. Matrix dependent impact of sugar and ascorbic acid addition on color and anthocyanin stability of black carrot, elderberry and strawberry single strength and from concentrate juices upon thermal treatment. Food Research International 42(8):1023-1033, 2009.

158. A Rawson et al. Effect of thermosonication on bioactive compounds in watermelon juice. Food Research International 44(5):1168-1173, 2011.

159. Z Chao et al. Comparison of thermal, ultraviolet-c, and high pressure treatments on quality parameters of watermelon juice. Food Chemistry 126(1):254-260, 2011.

160. AAL Tribst et al. Quality of mango nectar processed by high-pressure homogenization with optimized heat treatment. Journal of Food Science 76(2):M106-M110, 2011.

161. J Ahmed, US Shivhare, and K Mandeep. Thermal colour degradation kinetics of mango puree. International Journal of Food Properties 5(2):359-366, 2002.

162. I Scibisz et al. Mid-infrared spectroscopy as a tool for rapid determination of internal quality parameters in tomato. Food Chemistry 125(4):1390-1397, 2011.

163. AA Gowen et al. Hyperspectral imaging-An emerging process analytical tool for food quality and safety control. Trends in Food Science \& Technology 18(12):590-598, 2007.

164. Q Jianwei and L Renfu. Measurement of the optical properties of fruits and vegetables using spatially resolved hyperspectral diffuse reflectance imaging technique. Postharvest Biology and Technology 49(3):355-365, 2008.

165. N Nguyen Do Trong et al. Prediction of optimal cooking time for boiled potatoes by hyperspectral imaging. Journal of Food Engineering 105(4):617-624, 2011. 
166. P Onsekizoglu, KS Bahceci, and MJ Acar. Clarification and the concentration of apple juice using membrane processes: A comparative quality assessment. Journal of Membrane Science 352(1-2):160-165, 2010.

167. JP Yuan and F Chen. Degradation of ascorbic acid in aqueous solution. Journal of Agricultural and Food Chemistry 46(12):5078-5082, 1998.

168. R Garcia-Torres et al. Effects of dissolved oxygen in fruit juices and methods of removal. Comprehensive Reviews in Food Science and Food Safety 8(4):409-423, 2009.

169. I Oley et al. Temperature and pressure stability of L-ascorbic acid and/or [6s] 5-methyltetrahydrofolic acid: A kinetic study. European Food Research and Technology 223(1):71-77, 2006.

170. GD Sadler, J Roberts, and J Cornell. Determination of oxygen solubility in liquid foods using dissolvedoxygen electrode. Journal of Food Science 53(5):1493-1496, 1988.

171. MG Corradini and M Peleg. Prediction of vitamin loss during non-isothermal heat processes and storage with non-linear kinetic models. Trends in Food Science \& Technology 17:24-34, 2006.

172. A Serpen and V Gökmen. Reversible degradation kinetics of ascorbic acid under reducing and oxidizing conditions. Food Chemistry 104(2):721-725, 2007.

173. $\mathrm{C}$ Mertz et al. Characterization and thermal lability of carotenoids and vitamin $\mathrm{C}$ of tamarillo fruit (Solanum betaceum Cav.). Food Chemistry 119(2):653-659, 2010.

174. A Landl et al. Effect of high pressure processing on the quality of acidified Granny Smith apple purée product. Innovative Food Science \& Emerging Technologies 11(4):557-564, 2010.

175. G Pataro, G Donsì, and G Ferrari. Aseptic processing of apricots in syrup by means of a continuous pilot scale ohmic unit. LWT_Food Science and Technology 44(6):1546-1554, 2011.

176. C Dhuique-Mayer et al. Thermal degradation of antioxidant micronutrients in Citrus juice: Kinetics and newly formed compounds. Journal of Agricultural and Food Chemistry 55(10):4209-4216, 2007.

177. MC Manso et al. Modelling ascorbic acid thermal degradation and browning in orange juice under aerobic conditions. International Journal of Food Science and Technology 36(3):303-312, 2001.

178. M Karhan et al. Kinetic modeling of anaerobic thermal degradation of ascorbic acid in rose hip (Rosa canina L) pulp. Journal of Food Quality 27(5):311-319, 2004.

179. MW Davey, K Kenis, and J Keulemans. Genetic control of fruit vitamin C contents. Plant Physiology 142(1):343-351, 2006.

180. RK Toor and GP Savage. Antioxidant activity in different fractions of tomatoes. Food Research International 38(5):487-494, 2005.

181. AL Vasquez-Caicedo et al. Effects of thermal processing and fruit matrix on beta-carotene stability and enzyme inactivation during transformation of mangoes into puree and nectar. Food Chemistry 102(4):1172-1186, 2007.

182. HS Lee and GA Coates. Thermal pasteurization effects on color of red grapefruit juices. Journal of Food Science 64(4):663-666, 1999.

183. L Cinquanta et al. Effect on orange juice of batch pasteurization in an improved pilot-scale microwave oven. Journal of Food Science 75(1):E46-E50, 2010.

184. JJT Gama and CM de Sylos. Effect of thermal pasteurization and concentration on carotenoid composition of Brazilian Valencia orange juice. Food Chemistry 100(4):1686-1690, 2007.

185. A Fratianni, L Cinquanta, and G Panfili. Degradation of carotenoids in orange juice during microwave heating. LWT_Food Science and Technology 43(6):867-871, 2010.

186. $\mathrm{CH}$ Lin and BH Chen. Stability of carotenoids in tomato juice during processing. European Food Research and Technology 221(3-4):274-280, 2005.

187. C Seybold et al. Changes in contents of carotenoids and vitamin E during tomato processing. Journal of Agricultural and Food Chemistry 52(23):7005-7010, 2004.

188. AA Abushita, HG Daood, and PA Biacs. Change in carotenoids and antioxidant vitamins in tomato as a function of varietal and technological factors. Journal of Agricultural and Food Chemistry 48(6):20752081, 2000.

189. V Dewanto et al. Thermal processing enhances the nutritional value of tomatoes by increasing total antioxidant activity. Journal of Agricultural and Food Chemistry 50(10):3010-3014, 2002.

190. E Mayer-Miebach et al. Thermal processing of carrots: Lycopene stability and isomerisation with regard to antioxidant potential. Food Research International 38(8-9):1103-1108, 2005.

191. RK Toor and GP Savage. Effect of semi-drying on the antioxidant components of tomatoes. Food Chemistry 94(1):90-97, 2006.

192. D Dutta, UR Chaudhuri, and R Chakraborty. Effect of thermal treatment on the beta-carotene content, colour and textural properties of pumpkin. Journal of Food Science and Technology-Mysore 43(6):607$611,2006$. 
193. SK Sharma and M le Maguer. Kinetics of lycopene degradation in tomato pulp solids under different processing and storage conditions. Food Research International 29(3/4):309-315, 1996.

194. WW Fish and AR Davis. The effects of frozen storage conditions on lycopene stability in watermelon tissue. Journal of Agricultural and Food Chemistry 51(12):3582-3585, 2003.

195. W Stahl and H Sies. Uptake of lycopene and its geometrical-isomers is greater from heat-processed than from unprocessed tomato juice in humans. Journal of Nutrition 122(11):2161-2166, 1992.

196. K Frohlich et al. Effects of ingestion of tomatoes, tomato juice and tomato puree on contents of lycopene isomers, tocopherols and ascorbic acid in human plasma as well as on lycopene isomer pattern. British Journal of Nutrition 95(4):734-741, 2006.

197. KH van het Hof et al. Carotenoid bioavailability in humans from tomatoes processed in different ways determined from the carotenoid response in the triglyceride-rich lipoprotein fraction of plasma after a single consumption and in plasma after four days of consumption. Journal of Nutrition 130(5):11891196, 2000.

198. DB Rodriguez-Amaya. Quantitative analysis, in vitro assessment of bioavailability and antioxidant activity of food carotenoids-A review. Journal of Food Composition and Analysis 23(7):726-740, 2010.

199. EA Tydeman et al. Effect of carrot (Daucus carota) microstructure on carotene bioaccessibilty in the upper gastrointestinal tract. 1. In vitro simulations of carrot digestion. Journal of Agricultural and Food Chemistry 58(17):9847-9854, 2010.

200. EA Tydeman et al. Effect of carrot (Daucus carota) microstructure on carotene bioaccessibility in the upper gastrointestinal tract. 2. In vivo digestions. Journal of Agricultural and Food Chemistry 58(17):9855-9860, 2010.

201. RM Faulks and S Southon. Challenges to understanding and measuring carotenoid bioavailability. Biochimica Et Biophysica Acta-Molecular Basis of Disease 1740(2):95-100, 2005.

202. CA Svelander et al. Processing of tomato: Impact on in vitro bioaccessibility of lycopene and textural properties. Journal of the Science of Food and Agriculture 90(10):1665-1672, 2010.

203. O Livny et al. beta-carotene bioavailability from differently processed carrot meals in human ileostomy volunteers. European Journal of Nutrition 42(6):338-345, 2003.

204. S Van Buggenhout et al. In vitro approaches to estimate the effect of food processing on carotenoid bioavailability need thorough understanding of process induced microstructural changes. Trends in Food Science \& Technology 21(12):607-618, 2010.

205. S Van Buggenhout et al. Pectins in processed fruits and vegetables: Part III-Texture engineering. Comprehensive Reviews in Food Science and Food Safety 8(2):105-117, 2009.

206. CMGC Renard. Effects of conventional boiling on the polyphenols and cell walls of pears. Journal of the Science of Food and Agriculture 85(2):310-318, 2005.

207. C Le Bourvellec et al. Phenolic and fiber composition of applesauce is close to that of apple flesh. Journal of Food Composition and Analysis 24:537-547, 2011.

\section{AUTHOR QUERIES}

[AQ1] Please check if the edit to the sentence starting "The attributes such ..." is ok.

[AQ2] Please specify footnotes "a" and "b" inside Table 16.1.

[AQ3] Please provide the publisher location for Ref. [11].

[AQ4] Refrences [51,119] are exactly one and the same. So we have deleted the repeated version and renumbered the reference list and text citation in sequential order Please check.

[AQ5] Please provide the publisher location for Ref. [79].

[AQ6] Please provide the page range for Ref. [89]. 